\title{
Orbital changes, variation in solar activity and increased anthropogenic activities: controls on the Holocene flood frequency in the Lake Ledro area, Northern Italy
}

\author{
B. Vannière ${ }^{1}$, M. Magny ${ }^{1}$, S. Joannin ${ }^{1,2}$, A. Simonneau ${ }^{3}$, S. B. Wirth ${ }^{4}$, Y. Hamann ${ }^{4}$, E. Chapron ${ }^{3}$, A. Gilli ${ }^{4}$, \\ M. Desmet ${ }^{5}$, and F. S. Anselmetti ${ }^{6}$ \\ ${ }^{1}$ CNRS, UMR6249, Chrono-Environnement, Université de Franche-Comté, Besançon, France \\ ${ }^{2}$ LGL TPE, Université Lyon 1, Villeurbanne, France \\ ${ }^{3}$ ISTO, UMR 7327, CNRS, University of Orléans, BRGM, France \\ ${ }^{4}$ Geological Institute, ETH Zurich, Switzerland \\ ${ }^{5}$ GéHCO, UFR ST, Université Francois Rabelais, Tours, France \\ ${ }^{6}$ Institute of Geological Sciences and Oeschger Centre for Climate Change Research, University of Bern, Switzerland \\ Correspondence to: B. Vannière (boris.vanniere@univ-fcomte.fr)
}

Received: 4 September 2012 - Published in Clim. Past Discuss.: 24 September 2012

Revised: 29 April 2013 - Accepted: 30 April 2013 - Published: 31 May 2013

\begin{abstract}
Two lacustrine sediment cores from Lake Ledro in northern Italy were studied to produce chronologies of flood events for the past $10000 \mathrm{yr}$. For this purpose, we have developed an automatic method that objectively identifies the sedimentary imprint of river floods in the downstream lake basin. The method was based on colour data extracted from processed core photographs, and the count data were analysed to capture the flood signal. Flood frequency and reconstructed sedimentary dynamics were compared with lakelevel changes and pollen inferred vegetation dynamics. The results suggest a record marked by low flood frequency during the early and middle Holocene (10000-4500 cal BP). Only modest increases during short intervals are recorded at ca. 8000,7500 , and $7100 \mathrm{cal}$ BP. After $4500-4000 \mathrm{cal} \mathrm{BP}$, the record shows a shift toward increased flood frequency. With the exception of two short intervals around 2900-2500 and $1800-1400$ cal BP, which show a slightly reduced number of floods, the trend of increasing flood frequency prevailed until the 20th century, reaching a maximum between the 16th and the 19th centuries. Brief-flood frequency increases recorded during the early and middle Holocene can be attributed to cold climatic oscillations. On a centennial time scale, major changes in flood frequency, such as those observed after ca. $4500 / 4000$ and 500 cal BP, can be attributed to large-scale climatic changes such as the Neo-glacial and Little Ice Age,
\end{abstract}

which are under orbital and possibly solar control. However, in the Bronze Age and during the Middle Ages and modern times, forest clearing and land use probably partially control the flood activity.

\section{Introduction}

Understanding the respective roles of climate and land-use change on long-term ecosystem dynamics have become an important issue of palaeo-studies (Dearing et al., 2006; Hoffmann et al., 2010), particularly since the Ruddiman's hypothesis about the anthropogenic greenhouse era (2003, 2007). One of the main questions addresses the tipping elements that indicate ecosystems dynamics (Lenton et al., 2008) over the Holocene controlled by climatic or human forcing factors (Hoffmann et al., 2008; Magny et al., 2009). For instance, at the end of the Holocene Thermal Maximum ca. $5000 \mathrm{yr}$ ago (Renssen et al., 2009), southern European ecosystems experienced great changes, as observed in glacier dynamics (Matthews and Dresser, 2008), lake-levels (Magny et al., 2011), fire activity (Vannière et al., 2011) and flood records (Macklin and Lewin, 2003). In addition, the Bronze Age (4200-2800 cal BP) in Italy and across Europe was a crucial period for societal development, involving important 
technological innovations and changes in land-use strategies (Zolitschka et al., 2003; Valsecchi et al., 2006; Vannière et al., 2008).

River floods are among the most common and widespread natural disasters, and there is a societal debate about whether the frequency of such flood events varies due to changes in human land-use and/or climate change (Coulthard and Macklin, 2001; Chapron et al., 2005; Moreno et al., 2008). Several climate scenarios may trigger flood events. Flood chronologies from several regions suggest that times of rapid climate changes are associated with a greater frequency of large and extreme floods (Macklin et al., 2006; Vasskog et al., 2011). Records of palaeofloods show that natural floods resulting from excessive rainfall, snowmelt or both combined are highly sensitive to even modest changes of climate (Knox, 2000). Land use and human-driven land cover changes are also considered important forcing/controlling factors of flood activity and global sediment flux (Macklin and Lewin, 2003; Dearing and Jones, 2003).

Lakes provide valuable records of environmental changes because they are such sensitive ecosystems (Battarbee and Bennion, 2011), but also because their sediment accumulations offer exceptionally high-resolution, continuous terrestrial archives of past changes and a long-term perspective on ecosystem trajectories (Dearing et al., 2006). Sometimes, lake sedimentation may be very good at preserving riverflood activity at the event scale and offers continuous records of sedimentary flood deposits, which enables the estimation of long-term event frequency (Støren et al., 2010; Wilhelm et al., 2012; Gilli et al., 2013).

This paper presents a lacustrine approach to establish a Holocene flood record in southern Europe. This flood dataset is based on the chronological occurrence of detrital deposits in the sediment record of the perialpine Lake Ledro (Alps, Northern Italy). Two sediment cores were studied, and an automatic method was developed that objectively identifies the sedimentary imprint of river floods in the downstream lake basin. Geophysical and geochemical analyses made it possible to distinguish event deposits (flood and masswasting events) from background sedimentation. The reconstruction of flood frequency was compared with (1) lakelevel changes, which respond to longer-term variations in the hydrological regime, and (2) land-cover changes from pollen data, which also document land-use history. The principal objective of this paper is to highlight the main shift of Holocene ecosystem dynamics and to discuss the magnitude of such changes in the context of climatic versus human forcing factors.

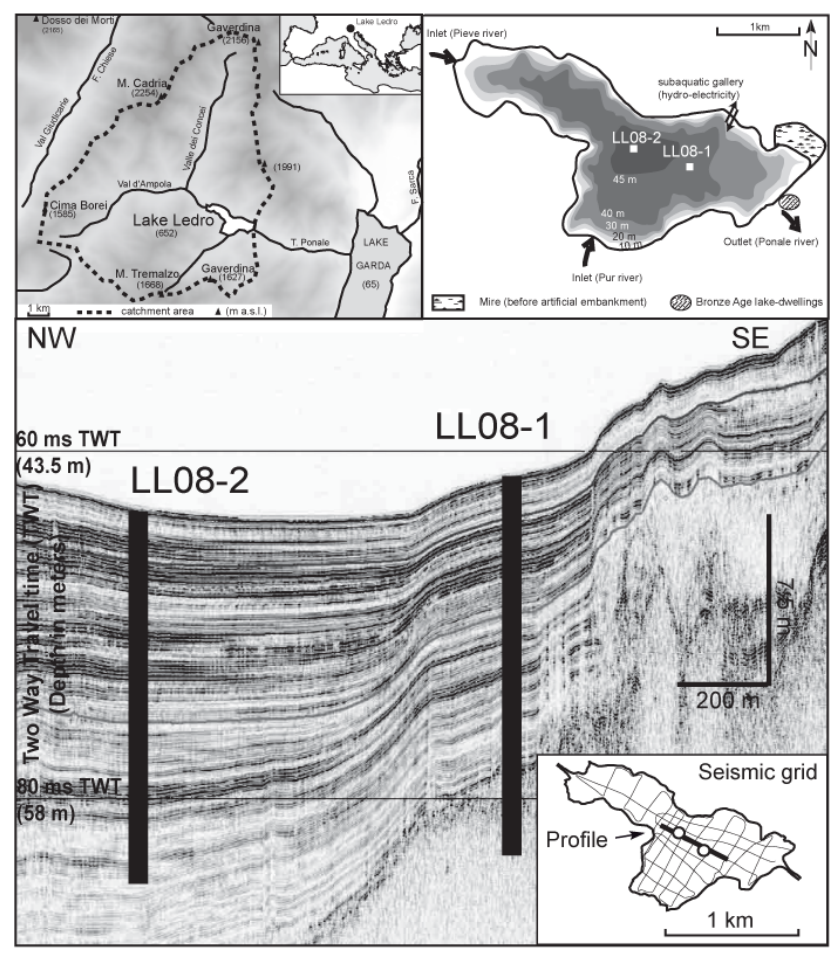

Fig. 1a. Location of Lake Ledro (Trentino, Italy) and its catchment (top-left panel); the bathymetry of the lake and positions of the coring sites, inlets, outlet and archaeological site (top-right panel); a NW-SE seismic profile, with positions of cores LL08-2 and LL08-1 (bottom panel).

\section{Site, materials and methods}

\subsection{Study site}

Lake Ledro ( $45^{\circ} 52^{\prime} \mathrm{N}, 10^{\circ} 45^{\prime} \mathrm{E}, 652 \mathrm{~m}$ a.s.l.), located on the southern slope of the Alps in Italy, is a small lake $\left(3.7 \mathrm{~km}^{2}\right)$ with a maximum depth of $46 \mathrm{~m}$ (Fig. 1a). The catchment area covers $111 \mathrm{~km}^{2}$ and includes several mountains that culminate between 1500 and $2250 \mathrm{~m}$ a.s.l. Two tributaries feed the lake: the Massangla and the Pur rivers. The lake was dammed by a moraine (Beug, 1964) that was partially cut by the outflowing Ponale River, which flows into nearby Lake Garda (65 m a.s.1.). Triassic, Liassic and Cretaceous limestone mainly constitutes the geological substratum. Some morainic tongues and alluvial deposits of calcareous and siliceous composition fill the bottom of the valleys. Lake sediments over the basin are dominated by autochthonous carbonate lake-marl that also forms a rim of white platform along the shore. The vegetation around the lake is dominated by beech (Fagus) mixed with fir (Abies). Higher in the Ledro Valley, the montane belt $(650-1600 \mathrm{~m})$ is characterised by spruce (Picea). The subalpine belt $(1600-2000 \mathrm{~m})$ is replaced by grasslands above $2000 \mathrm{~m}$.

At Lake Ledro, the modern climate conditions can be considered sub-continental (Beug, 1964). The coldest and 
the warmest months have average temperatures of 0 and $20^{\circ} \mathrm{C}$, respectively. The annual precipitation ranges $\sim 750$ to $1000 \mathrm{~mm}$. The recent synthesis of seasonal characteristics of flood regimes across the Alpine-Carpathian range by Parajka et al. (2010) indicates that, in the region of Lake Ledro, the annual maximum daily precipitation is distributed between late August and November.

During the 20th century, several river corrections have been installed in both tributaries of the lake in order to reduce the effects of flood events. Indeed, they are two temporary torrential tributaries and their drainage network is marked by canyons on steep slopes favouring intense gully erosion. On the River Ponale, between Lake Ledro and Lake Garda, the pumped-storage plant "Centrale idroelettrica del Ponale" was built in 1928-1929. Water is pumped in penstocks from Lake Garda to Lake Ledro, which is $532 \mathrm{~m}$ higher. This artificial water regulation strongly modifies the sedimentary dynamics. Consequently, the sedimentary record since 1929 cannot be compared to the older parts of the record or used as a reference. During construction of the pumped-storage plant, the remains of a Bronze Age pile-dwelling village (over 10000 piles) were discovered on the eastern shore of the Lake. Lake settlements started around 4000-3800 cal BP and ended with abandonment between 3200-2800 cal BP (Pinton and Carrara, 2007).

\subsection{Seismic survey and coring}

A seismic reflection survey using a single-channel $3.5 \mathrm{kHz}$ pinger source provided the lake bathymetry and highresolution sub-bottom profiles used to establish a seismic stratigraphy of the well preserved part of the basin infilling (Fig. 1a). Cores LL08-1 and LL08-2 were located in the deep basin (water depth: 45-46 m) within a well stratified seismic facies highlighting continuous and high-frequency reflections, i.e. by avoiding chaotic and larger mass-wasting deposits (MWD). Core LL08-1 (7 m core length) is in a relatively distal position from the two main deltas constructed by the lake tributaries, whereas core LL08-2 (11 m core length) is more proximal to the inflow of allochthonous particles (Fig. 1a, b). The sediment-water interface was properly recovered by using a gravity corer (LL08-1P and LL08-2P). Sediment cores were retrieved using a piston corer with the same liners (UWITEC system). Duplicate cores were taken from each site (LL08-1 and LL08-2).

\subsection{Geophysics logging}

Magnetic susceptibility (MS) and Gamma-ray attenuation bulk density (GD) were measured in the cores at $5 \mathrm{~mm}$ resolution with a Geotek multi-sensor core logger (Gunn and Best, 1998). GD was logged on whole cores and MS was measured on split cores with the MS2E1 surface-scanning sensor from Bartington Instruments, which was adapted for fine-resolution volume magnetic-susceptibility measure-

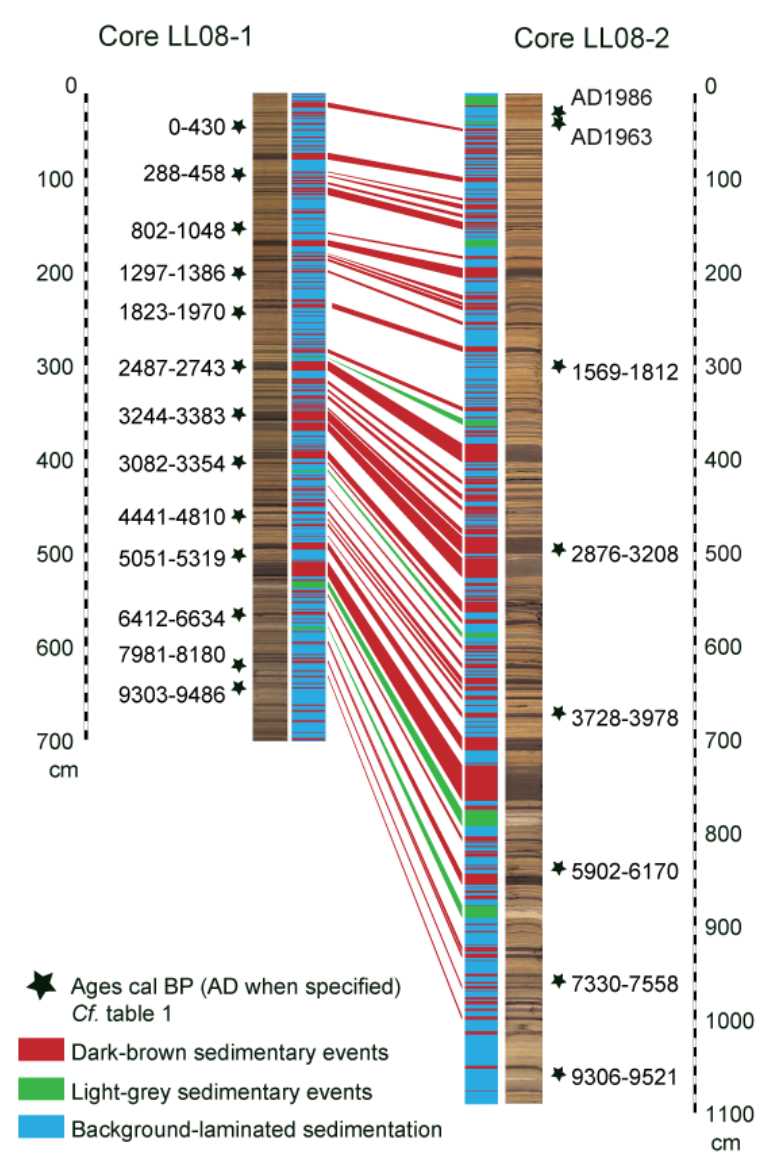

Fig. 1b. Sediment core images, lithology and ages from core LL081 and LL08-2.

ments (Vannière et al., 2004). These analyses allow us to establish stratigraphic correlations useful for constructing the master sequences (LL08-1 and LL08-2), guaranteeing complete records without any gaps or redundancies. Colour properties were analysed with a line scan camera with 3 CCDs (2048 pixels each). Colour data are reported in the RGB and Lab-colour systems at a resolution of $70 \mu \mathrm{m}$, providing a continuous record of the master sequences at very high resolution.

\subsection{Geochemical analysis}

The chemical composition of sediment core LL08-1 was analysed using an Avaatech XRF core scanner at a resolution of $0.2 \mathrm{~mm}$ (presented here: $\mathrm{Si}, \mathrm{Ca}, \mathrm{K}, \mathrm{Ti}$ ) and $2 \mathrm{~mm}$ $(\mathrm{Zr})$. The XRF measurements were carried out on split cores with a measurement duration of $20 \mathrm{~s}$. A $10 \mathrm{kV}$ voltage and a $2000 \mu \mathrm{A}$ current were applied to detect lighter elements ( $\mathrm{Si}$, $\mathrm{Ca}, \mathrm{K}, \mathrm{Ti}$ ), and $30 \mathrm{kV}$ and $1000 \mu \mathrm{A}$ settings were used for the heavier elements $(\mathrm{Zr})$. Because of the influences of variable water content and grain size on the sediment matrix, the XRF scanner only provides a rough estimate of the geochemical composition, and the acquired counts are semi-quantitative. 


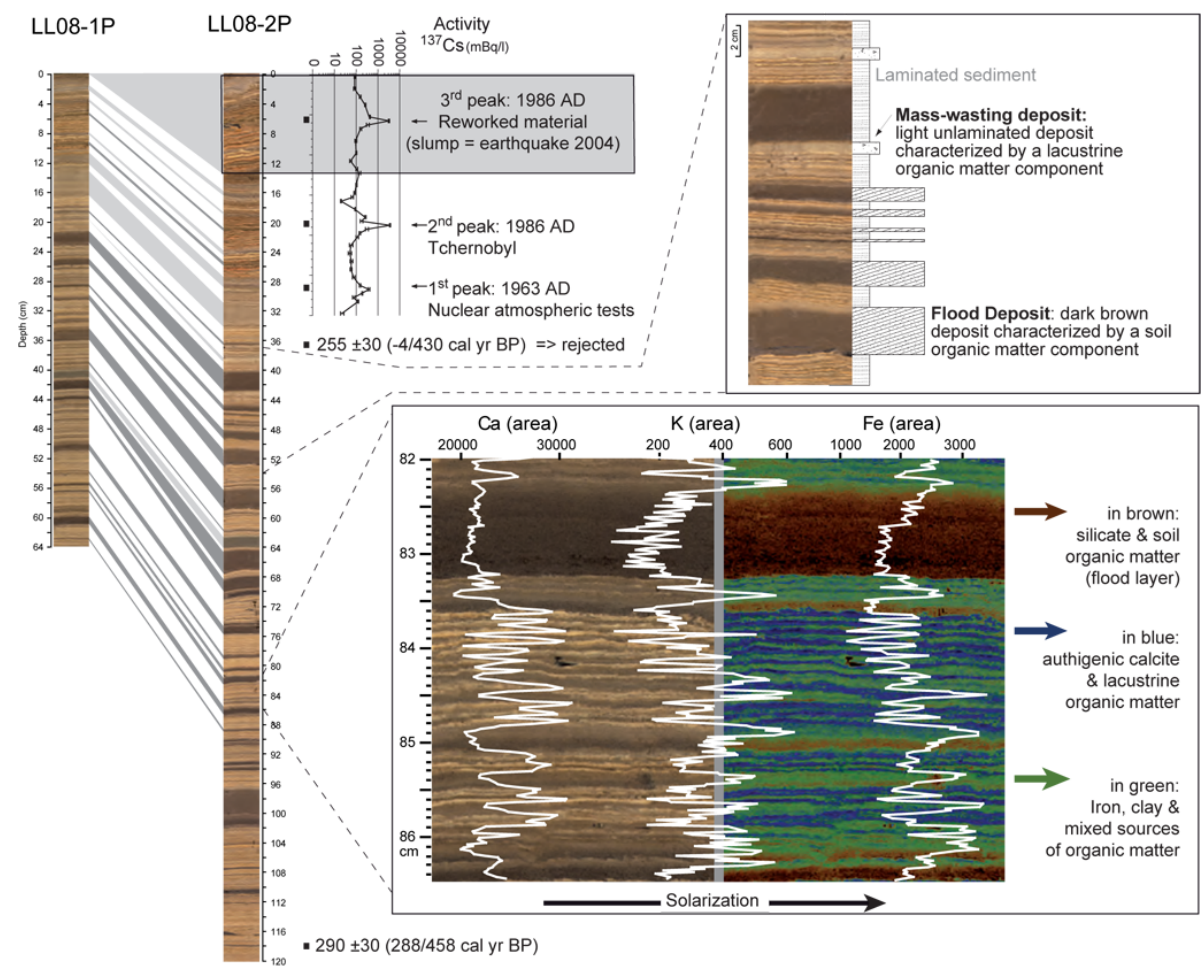

Fig. 2a. Sediment core images, ${ }^{137} \mathrm{Cs}$ measurements and radiocarbon dates from gravity cores (1P and 2P) sampled at sites of cores LL08-1 and LL08-2. Visual inspection of the cores from Lake Ledro shows a laminated yellow-grey sediment (background sediment) interspersed with fine-grained brown units that are usually rich in terrestrial organic matter corresponding to allochthonous event layers or flood deposits (FD; bottom zoom-box). Unlaminated mass-wasting deposits (MWD) were also identified and could be easily distinguished from FD by their light colour and their lacustrine organic component (top zoom-box). All of these deposits are considered to be instantaneous and were removed from the age-depth models (Fig. 4). Solarisation is an effect used in photography that causes an image recorded on a negative to be reversed in tone.

The Ca, Si, K, Fe, Ti and $\mathrm{Zr}$ results are presented for a short section to complete the lithological characterisation (Fig. 2a, $\mathrm{b}$ and $\mathrm{c})$. We present here only elements that offer a significant variability without too much noise. To calibrate the XRF measurements and to analyse selected layers, 49 samples from the laminated facies of LL08-1 were processed for inductively coupled plasma-atomic emission spectrometry (ICP-AES) measurements. Approximately $80 \mathrm{mg}$ of sediment were fully dissolved under pressure at $100^{\circ} \mathrm{C}$ using a mixture of $2 \mathrm{~mL}$ each of suprapure grade $\mathrm{HCl}, \mathrm{HNO}_{3}$ and HF. After evaporation, the residues were mixed again with $\mathrm{HNO}_{3}$ and diluted with MilliQ water. Certified reference materials (BCSS1, JSD1, PACS1 and BCR2), 5 "white samples" (i.e. lacking sediment), and 5 duplicates were added to the set of samples. Only $\mathrm{Zr}$ and $\mathrm{Ca}$ elemental concentrations (ppm) are presented.

\subsection{Organic matter characterisation}

Twelve samples were taken from unlaminated brown and light grey deposits of LL08-1 for organic matter petrographic observations. Petrographic study (palynofacies) involves microscopic examination of total $\mathrm{OM}$ in transmitted and re- flected light after acid hydrolysis of carbonates and silicates. Taking into account the chromatic and textural aspects of particles (Meyers and Lallier-Vergès, 1999), the analysis aims to identify and quantify the organic compounds (relative percentages of surface particle area) and establish the ratio between allochthonous and autochthonous components. Terrestrial OM (TOM) includes particles weathered from the catchment and/or windblown grains, while lacustrine OM (LOM) consists of particles derived from aquatic plants and phytoplankton (Millet et al., 2007).

\subsection{Pollen analyses}

For pollen analyses, the mean sampling resolution $\left(1 \mathrm{~cm}^{2}\right.$ and $1 \mathrm{~cm}$ thickness) on the whole LL08-1 sequence is $5 \mathrm{~cm}$. Samples were taken from laminated parts of the series. Samples were treated chemically $(\mathrm{HCl}, \mathrm{KOH}, \mathrm{HF}$, acetolysis) and physically $(0.5 \mathrm{~mm}$ sieving and decanting) following standard procedures (Moore et al., 1991). Lycopodium markers (Stockmaar, 1971) were added to estimate pollen concentrations (grains $\mathrm{cm}^{-3}$ ). For the identification of pollen types, we used keys (Beug, 2004; Reille, 1992-1998) as well as the reference collection at the University of Franche-Comté. At 


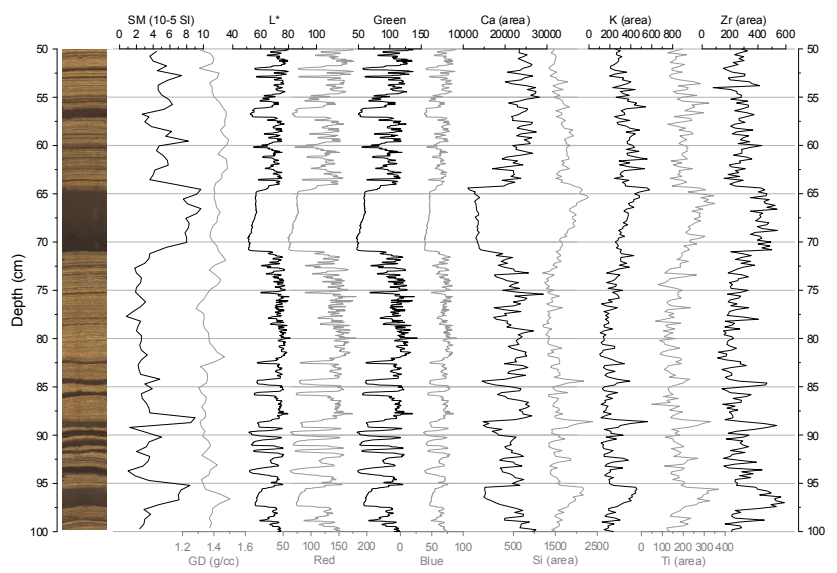

Fig. 2b. Sediment core images, Magnetic Susceptibility (MS) and Gamma Density (GD) measurements, CIE_L* and RGB colour data, and main elements from XRF measurements of a $50 \mathrm{~cm}$ long section from core LL08-1.

least 300 terrestrial pollen grains were counted in total, excluding dominant terrestrial taxa, water and wetland plants, as well as spores of pteridophytes. This paper presents only arboreal and non-arboreal pollen (AP/NAP) curves and an "anthropic" pollen-sum curve (Cerealia type, Secale type, Triticum type, Cannabis-humulus type, Plantago lanceolata, Rumex, Urticaceae). A related paper (Joannin et al., 2013) is dedicated to the reconstruction of detailed vegetation dynamics around Lake Ledro.

\section{$2.7{ }^{14} \mathrm{C}$ and ${ }^{137} \mathrm{Cs}$ measurements}

The chronology is based on 19 AMS ${ }^{14} \mathrm{C}$ ages measured on terrestrial plant macrofossils and on ${ }^{137} \mathrm{Cs}$ measurements taken from the topmost $32 \mathrm{~cm}$ of the sediment record with a well-type GeLi detector following procedures detailed in Fanetti et al. (2008; Table 1 and Fig. 2a). For radiocarbon analyses, selected terrestrial macrofossils were isolated from sediment samples (thickness of $1 \mathrm{~cm}$ ) by sieving with a $100 \mu \mathrm{m}$ mesh under water. All radiocarbon ages were calibrated using the program Calib 6.06 with the Intcal09 calibration set (Reimer et al., 2009). All ages are reported on each master core (LL08-1 and LL08-2) according to lithological correlation (Fig. 2a). The results from radiocarbon and short-lived radio-isotope analyses were combined to produce an age-depth model for each sequence using a smooth cubic spline model available within the "Clam" software by Blaauw (2010).

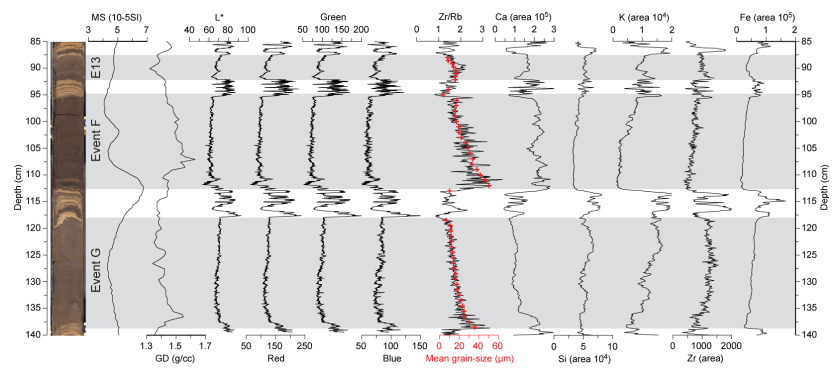

Fig. 2c. Sediment core images, Magnetic Susceptibility (MS) and Gamma Density (GD) measurements, CIE_L* and RGB colour data, and main elements from XRF measurements of a $55 \mathrm{~cm}$ long section from core LL08-2 (B1a), where 2 thick flood deposits are recorded: event $\mathrm{E}$ and $\mathrm{F}$.

\section{Results}

\subsection{Lithology and geochemistry: laminated facies and sedimentary events}

Lake Ledro's sedimentation is dominated by calcite precipitation and biogenic lake productivity, accompanied by the sedimentation of allochthonous material such as clay and organic particles. This results in a laminated and continuously deposited facies, referred to as "background" sedimentation characterised by biogeochemical calcite varves (Lotter et al., 1997). In detail, the background-laminated sedimentation is composed of two millimetric or sub-millimetric layers. Based on thin sections on selected part of the cores and core scanner XRF analysis, there are a white calcium rich layer and a gray clayey organic and iron rich layer (Fig. 2a). Lake Ledro basin fill was composed of finely laminated background sediments since ca. 10 000-9500 cal. yr BP. The solarisation (saturated and inversed colour) of core images allows to easily distinct the 2 different laminae that characterise background lacustrine sedimentation in Lake Ledro, and highlighting that this finely laminated facies is frequently intercalated by numerous event deposits of two different types (Fig. 2a).

The first type of sedimentary event corresponds to graded dark-brown deposits of various thicknesses (from $1 \mathrm{~mm}$ to $38 \mathrm{~cm}$ ). Geochemical and geophysical measurements also allow us to distinguish these dark-brown layers from the background sedimentation. They are in general characterised by higher magnetic susceptibility and an upward increase in the detrital elements such as $\mathrm{Si}, \mathrm{K}$, Ti and $\mathrm{Zr}$ (Fig. 2b). However, there is some variability in elemental composition of the dark-brown deposits as for example event $\mathrm{F}$ contains a higher amount of $\mathrm{Ca}$, which compensates the amount of detrital elements (Fig. 2c) and varies the organic matter content. Laser grain-size analyses revealed that all these sedimentary events are graded (mean grain-size $<60 \mu \mathrm{m}$; detailed data are presented in Simonneau et al., 2013; Fig. 2c) and some of them contain an inverse (coarsening upward) grading at the base 
Table 1. Radiocarbon and ${ }^{137}$ Cs ages of cores LL08-1 and LL08-2, with the correlations between them.

\begin{tabular}{|c|c|c|c|c|c|c|c|c|c|}
\hline \multicolumn{4}{|c|}{ Radiocarbon age core LL080-1 ( $1 \mathrm{~cm}$ thick sample) } & \multicolumn{3}{|c|}{ Correlation with core LL08-2 } & \multirow{2}{*}{$\begin{array}{l}{ }^{14} \mathrm{C} \text { Age } \\
\mathrm{BP}\end{array}$} & \multirow{2}{*}{$\begin{array}{r}\text { Calibrated age* } \\
2 \sigma \mathrm{cal} \mathrm{BP}\end{array}$} & \multirow[t]{2}{*}{ Materia } \\
\hline Lab. code & Sect ${ }^{\circ}$ Name & Sect ${ }^{\circ}$ Depth & MC Depth & Sect ${ }^{\circ}$ Name & Sect ${ }^{\circ}$ Depth & MC Depth & & & \\
\hline POZ-27888** & P2 & 30 & 16.5 & LL082-P & 38.5 & 21.7 & $255 \pm 30$ & $-4-430$ & Wood-Peat-Charcoal \\
\hline POZ-30216 & $\mathrm{P} 1 \mathrm{~b}$ & 17 & 82.2 & LL082-P & 113.5 & 96.7 & $290 \pm 30$ & $288-458$ & Wood-Peat-Charcoal \\
\hline POZ-30218 & $\mathrm{P} 1 \mathrm{~b}$ & 77 & 142.2 & LL082-A1a & 53.5 & 190.7 & $1020 \pm 30$ & $802-1048$ & Wood-Peat-Charcoal \\
\hline POZ-30219 & $\mathrm{A} 2 \mathrm{a}$ & 68 & 193.8 & LL082-A1a & 148 & 285.2 & $1445 \pm 30$ & $1297-1386$ & Wood-Peat-Charcoal \\
\hline POZ-30220 & $\mathrm{A} 2 \mathrm{a}$ & 113 & 238.8 & LL082-A1b & 40.5 & 335.1 & $1945 \pm 30$ & $1823-1970$ & Wood-Peat-Charcoal \\
\hline POZ-30221 & A3a & 36 & 298.8 & LL082-B1a & 17.5 & 443.1 & $2520 \pm 35$ & $2487-2743$ & Wood-Peat-Charcoal \\
\hline POZ-27890 & A3a & 88 & 350.8 & LL082-B1a & 112 & 537.6 & $3095 \pm 30$ & $3244-3383$ & Wood-Peat-Charcoal \\
\hline POZ-30222 & $\mathrm{B} 2 \mathrm{a}$ & 21 & 402.6 & LL082-B1b & 46.5 & 626 & $3030 \pm 35$ & $3082-3354$ & Wood-Peat-Charcoal \\
\hline POZ-27891 & $\mathrm{B} 2 \mathrm{a}$ & 80 & 461.6 & LL082-A2a & 40 & 713.3 & $4080 \pm 35$ & $4441-4810$ & Wood-Peat-Charcoal \\
\hline POZ-30223 & $\mathrm{A} 3 \mathrm{~b}$ & 91 & 499.2 & LL082-A2a & 91 & 764.3 & $4550 \pm 35$ & $5051-5319$ & Wood-Peat-Charcoal \\
\hline POZ-27892 & $\mathrm{B} 2 \mathrm{~b}$ & 20 & 562.4 & LL082-A2b & 73 & 896.9 & $5720 \pm 40$ & $6412-6634$ & Wood-Peat-Charcoal \\
\hline POZ-30224 & $\mathrm{A} 4 \mathrm{a}$ & 46 & 616 & LL082-B2a & 54 & 1011.3 & $7270 \pm 50$ & $7981-8180$ & Wood-Peat-Charcoal \\
\hline POZ-27894 & $\mathrm{B} 2 \mathrm{~b}$ & 109 & 641.5 & LL082-B2a & 104.5 & 1061.8 & $8385 \pm 35$ & $9303-9486$ & Wood-Peat-Charcoal \\
\hline \multicolumn{4}{|c|}{ Radiocarbon age core LL080-2 ( $1 \mathrm{~cm}$ thick sample) } & \multicolumn{3}{|c|}{ Correlation with core LL08-1 } & ${ }^{14} \mathrm{C}$ Age & Calibrated age* & Material \\
\hline ETH-39232 & Alb & 8.5 & 303.1 & $\mathrm{~A} 2 \mathrm{a}$ & 84.5 & 210.5 & $1765 \pm 35$ & $1569-1812$ & leaf remains \\
\hline ETH-40410 & B1a & 68 & 493.6 & A3a & 65 & 328.1 & $2890 \pm 50$ & $2876-3208$ & leaf remains \\
\hline ETH-40411 & $\mathrm{B} 1 \mathrm{~b}$ & 86.5 & 666 & B2a & 43 & 424.9 & $3575 \pm 35$ & $3728-3978$ & leaf remains \\
\hline ЕTH-39233 & $\mathrm{A} 2 \mathrm{~b}$ & 16 & 839.9 & $\mathrm{~A} 3 \mathrm{~b}$ & 127 & 535.8 & $5200 \pm 35$ & $5902-6170$ & leaf remains \& needles \\
\hline ETH-39234 & $\mathrm{A} 2 \mathrm{~b}$ & 136.5 & 960.4 & $\mathrm{~A} 4 \mathrm{a}$ & 19 & 589 & $6530 \pm 40$ & $7330-7558$ & needles \\
\hline ETH-39235 & $\mathrm{B} 2 \mathrm{a}$ & 108 & 1065.3 & $\mathrm{~A} 4 \mathrm{a}$ & 73 & 643 & $8405 \pm 40$ & $9306-9521$ & needles \\
\hline \multicolumn{4}{|c|}{${ }^{137} \mathrm{Cs}$ age core LL080-2 (0.5 $\mathrm{cm}$ thick sample) } & \multicolumn{3}{|c|}{ Correlation with core LL08-1 } & ${ }^{137}$ Cs Age & & \\
\hline${ }^{137} \mathrm{Cs} 86 \mathrm{~d}$ & $\mathrm{P}$ & 10.25 & & & & & 1986 doubling & & sediment bulk \\
\hline${ }^{137} \mathrm{Cs} 86$ & $\mathrm{P}$ & 23.25 & 6.45 & P1a & 8.75 & 4.55 & 1986 real & $-37--35$ & sediment bulk \\
\hline${ }^{137} \mathrm{Cs} 63$ & $\mathrm{P}$ & 31.25 & 14.45 & P1a & 15.5 & 11.3 & 1963 & $-14--12$ & sediment bulk \\
\hline
\end{tabular}

* Calibrated with Calib 6.0 (Reimer et al., 2009); ** Age rejected.

followed by normal (fining upward) grading (see event E; Fig. 2c). This grain-size pattern is closely reproduced by the elemental $\mathrm{Zr} / \mathrm{Rb}$ ratio, which is proposed in the literature as a grain-size proxy (Schneider et al., 1997). This reflect the temporal increase in river discharge (coarsening upwards) and the subsequent decrease (finning upwards), as shown in the literature (Mulder et al., 2003; Mulder and Chapron, 2011; Gilli et al., 2013). If such an inverse grading is present, then it is a clear indication for a flood-related deposit. The thickness of the coarse basal sub-layer can strongly vary and can reach a thickness of several $\mathrm{cm}$, but is often not visible by naked eye for thin flood deposit $(<1 \mathrm{~cm})$. As the upper boundary of the coarse basal layer is a gradual in its nature, it would not be feasible to unambiguously determine the thickness of this basal layer. For all dark-coloured events, they are not well sorted, except at the top of the deposits where we can observe sometimes the formation of a thin clay cap. Organic petrography observations show that organic matter included in these deposits is mainly of terrestrial origin (red amorphous organic particles; Meyers and Lallier-Vergès, 1999). Although the elemental composition of these deposits can slightly vary, these events can properly be distinguished from the background sediment in the colour data (Fig. $2 \mathrm{~b}$ and c). The grading pattern in combination with the elemental and organic composition observed in these deposits is interpreted as the typical signature of hyperpycnal flood deposits in a sub-aquatic basin (Mulder and Alexander, 2001; Mulder and
Table 2. Descriptive statistics of flood deposits from both cores and methods.

\begin{tabular}{lrrrrr}
\hline \multirow{2}{*}{ Core } & \multicolumn{2}{c}{ LL08-1 } & & \multicolumn{2}{c}{ LL08-2 } \\
\cline { 2 - 3 } \cline { 6 - 6 } Counting method & Automatic & Naked-eye & & Automatic & Naked-eye \\
\hline Number of values & 387 & 408 & & 507 & 482 \\
Sum of thickness $(\mathrm{cm})$ & 206.1 & 219.8 & & 378.1 & 419.8 \\
Minimum & 0.03 & 1.00 & & 0.03 & 0.09 \\
Maximum & 14.8 & 16.0 & & 37.5 & 38.0 \\
Mean & 0.53 & 0.54 & & 0.75 & 0.87 \\
Median & 0.13 & 0.20 & & 0.15 & 0.20 \\
First quartile & 0.06 & 0.10 & & 0.06 & 0.10 \\
Third quartile & 0.41 & 0.40 & & 0.42 & 0.50 \\
Standard deviation & 1.32 & 1.33 & & 2.45 & 2.60 \\
\hline
\end{tabular}

Chapron, 2011; Gilli et al., 2013; Simonneau et al., 2013). Several hundred of these flood deposits are recorded within core LL08-1 and LL08-2 (Table 2). Visual correlations between master cores LL08-1 and LL08-2 show that floodevent deposits are quasi-systematically thicker in core LL082 , i.e. at the more delta-proximal location. In other words, a part of deposits were too thin to be detected in the delta-distal core LL08-1 or are not recorded by a sedimentary deposit because the flood intensity was too low and sediments do not reach this position. Thus, $20 \%$ more flood event deposits have been identified and counted in core LL08-2 compared to core LL08-1.

In addition to these flood deposits, a second sedimentary event type can be observed as light grey-brown homogeneous 
deposits (Fig. 2a). The mean granulometry of these event layers is finer, better sorted and no graded (mean grain-size $<25 \mu \mathrm{m}$; Simonneau et al., 2013); therefore, petrographic observations show that this facies is mainly composed of organic matter of lacustrine origin (grey amorphous particles; Millet et al., 2007). These are the same particles that also characterise the laminated facies, indicating their origin in the lake's biological productivity. Thus, these light grey-brown homogeneous deposits are of lacustrine origin and may correspond to subaquatic mass-movements or masswasting deposits (MWD) reworking and mixing lacustrine sediments from the slopes and the shores (Simonneau et al., 2013). This second type of sedimentary event is indicated by a layer thickness ranging from $0.1 \mathrm{~mm}$ to $13 \mathrm{~cm}$. This second type of event deposit is much less common than the dark-brown one; 11 and 13 deposits (of more than $1.5 \mathrm{~cm}$ thickness) have been identified, respectively, in LL08-1 and LL08-2 records, while several hundred flood event deposits have been observed. These MWDs were previously identified (Simonneau et al., 2013) and manually removed from the record before the image analysis.

\subsection{Chronology and sediment accumulation rates}

Measurements of ${ }^{137} \mathrm{Cs}$ radioactivity in the upper $32 \mathrm{~cm}$ of core LL08-2P highlight the occurrence of 3 well-defined peaks at 29, 20 and $6 \mathrm{~cm}$ (Fig. 2a). The deeper peak at $29 \mathrm{~cm}$ reflect the peak level of atmospheric nuclear weapons tests in the Northern Hemisphere in 1963 (Appleby, 2001), whereas the first very strong peak at $19 \mathrm{~cm}$ is related to the high contamination in northern Italy induced by the Chernobyl nuclear reactor meltdown in 1986 and previously documented within the Southern Alps in lake Como recent sediments (Fanetti et al., 2008). The upper peak at $6 \mathrm{~cm}$ also indicates that high contamination is very unusual. Because this high peak in ${ }^{137} \mathrm{Cs}$ reaches similar values as the one associated with the 1986 Chernobyl accident, and because lacustrine laminae are tilted between 0.5 and $13 \mathrm{~cm}$ of the sediment core, this section of core LL08-2P is interpreted as a slump deposit reworking recent sediments and should therefore not be considered in the development of the age-depth model. The chrono-stratigraphic position of this slump on the top of the gravity core suggests that it is linked with a really recent events and we hypothesis that is the result of the last earthquake recorded in the region in 2004. The 2004 slump deposit is laterally associated with a hummocky acoustic facies identified at the western edge of the lake basin on seismic profiles (Fig. 1a). No other hummocky facies are identified in the lake basin and no other tilted facies have been observed in the sequences. Therefore, these two coring sites where selected on seismic profiles away from chaotic acoustic facies produced by mass wasting deposits or from any hummocky acoustic facies. We are thus confident that no others slump deposits are intercalated within the sediment cores.

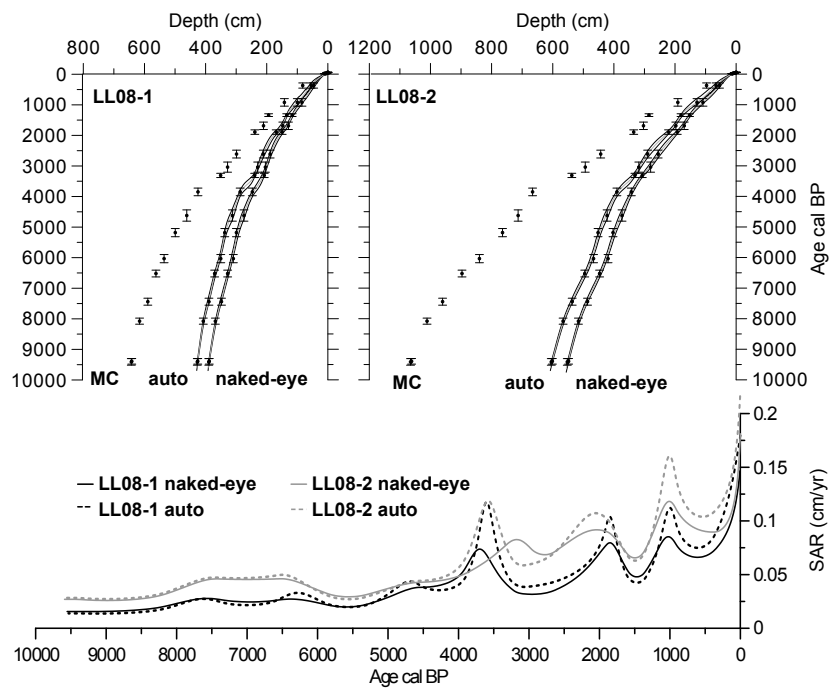

Fig. 3. Age/depth models and respective Sediment Accumulation Rate (SAR) from cores LL08-1 and LL08-2. MC: master core; Auto: without automatic count of flood deposits and naked-eye mass-wasting deposits; Naked-eye: without naked-eye count of sedimentary events (flood deposits and mass-wasting deposits). For detailed explanation of both sedimentary events counting methods see Sect. 3.3.

The results from radiocarbon dating and from the analysis of the anthropogenic radionuclide ${ }^{137} \mathrm{Cs}$ were combined to produce age-depth models for both cores using a smooth cubic spline model available within the "Clam" software (Blaauw, 2010; Fig. 3; Table 1). This model allows for the robust estimation of uncertainties and takes into account the entire probability distribution of the calibrated radiocarbon dates, avoiding any arbitrary choices. Taking into account the automatic and the naked-eye method for sedimentary event identification and counting (see next section), two age-depth models were calculated for each sequence. The average confidence interval of the error of the models is $200 \mathrm{yr}$. The mean Sediment Accumulation Rate (SAR) is higher for LL08-2 than for LL08-1, but both sequences show similar variability. The automatic method does not identify the clay cap of the sedimentary events, and thus it may underestimate the sedimentary event thickness, which explains the slight differences between the models. In general, however, the shape and slope of the curves are very similar. Considering the entire record at the scale of $10000 \mathrm{yr}$, the sedimentary dynamics deduced from all these models appears to be relatively continuous and low (SAR $<0.04 \mathrm{~mm} \mathrm{yr}^{-1}$ for sedimentation without sedimentary events) prior to $4000 \mathrm{cal} \mathrm{BP}$. After this date, a long trend of increasing SAR is recorded, as are abrupt and strong increases that reach maxima at ca. 3600 $1800,1000 \mathrm{yr}$ cal BP and since ca. $1850 \mathrm{cal}$ AD. 


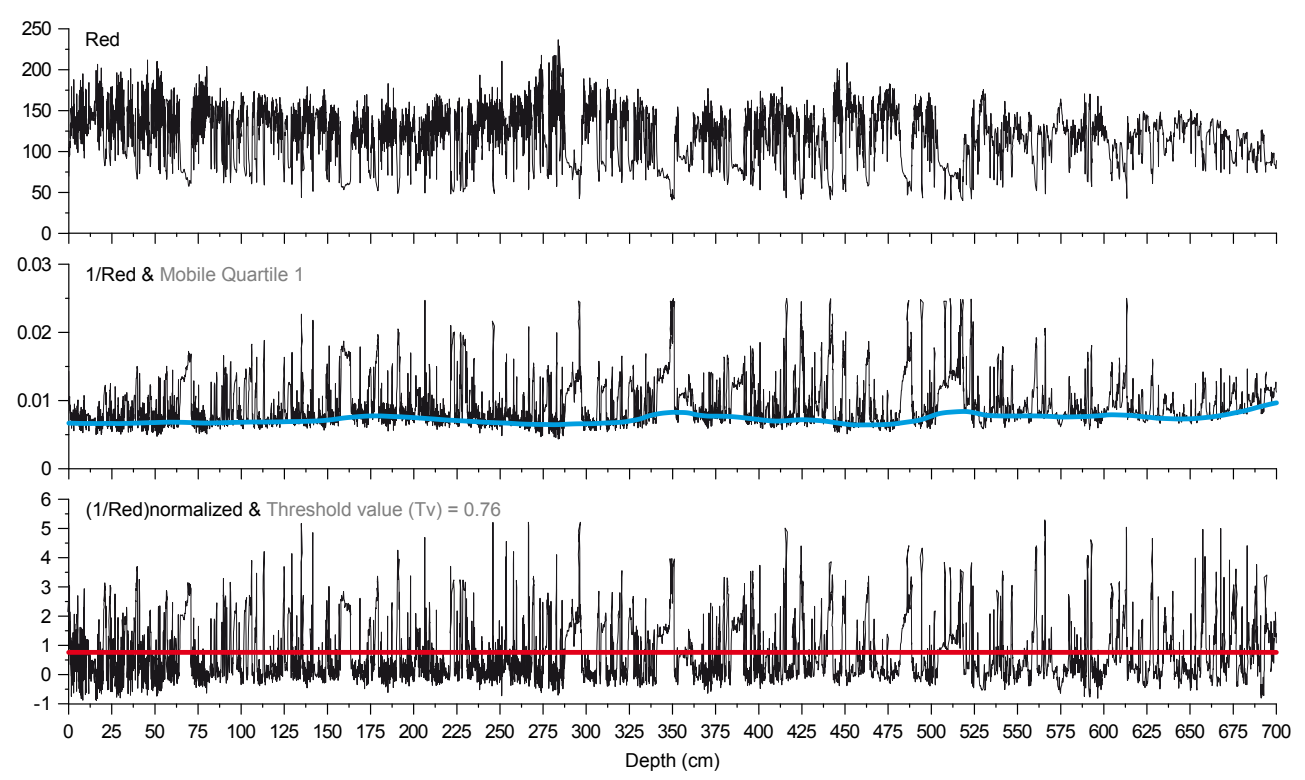

Fig. 4a. Raw and normalised red colour data from core LL08-1, and the threshold value detected with the Gaussian mixture model (Fig. 4b). $(1 /$ Red $)$ normalised $=(((1 /$ red $)$-mobile quartile1 $) /$ Mobile standard-deviation $)$; the running window is 1000 values.

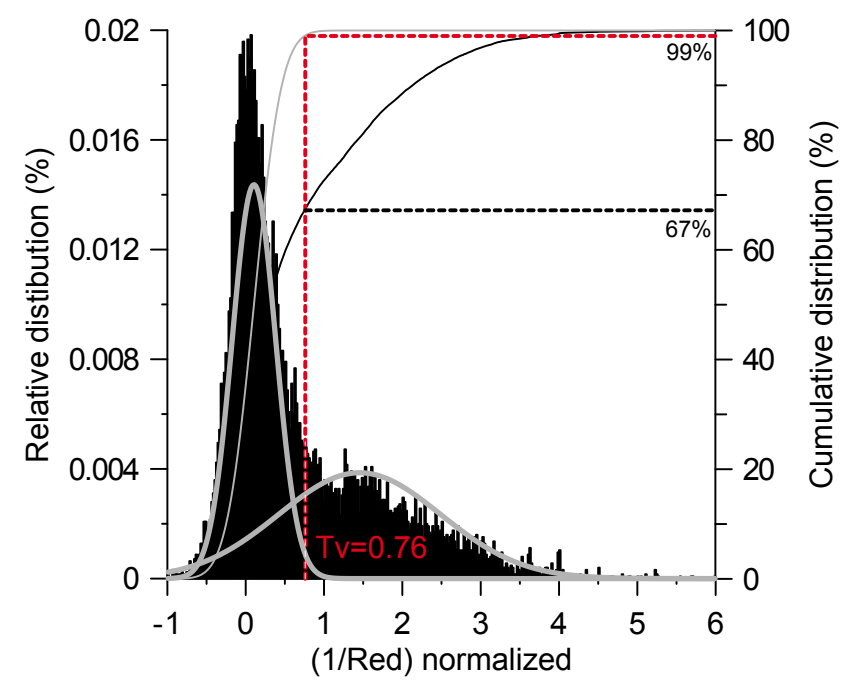

Fig. 4b. Gaussian mixture model of the normalised red colour data (Fig. 3a) used to disentangle two overlapping sub-distributions and to identify the upper limit of the main distribution (threshold value).

\subsection{Automatic and naked-eye counting of flood deposits, and frequency analysis}

Core-image treatment by solarisation shows that flood deposits appear in a brown colour that is mainly characterised by the red colour in RGB scale, whereas the laminated facies is characterised by blue for the summer deposit and by the green for the clayed layer (Fig. 2a). Thus, to separate the dark-brown deposits from the background, we selected the 1/Red signal, which represents the highest ampli- tude over the series in RGB values (Figs. $2 b$ and $4 a$ ). Then, we normalised the signal by removing the low-frequency trend, following the principle used for reconstruction of fireevent frequency (Long et al., 1998; Vannière et al., 2008). The low-frequency signal is estimated here by the moving first quartile with a running window of 1000 values. The normalisation corresponds to the reduced value (raw value minus the mobile quartile) divided by the mobile standard deviation: $(1 /$ Red $)$ normalised $=(((1 /$ Red $)$-mobile quartile1)/mobile standard-deviation). The normalised signal contains two components: the background, which oscillates around zero, and the peak component, which is significantly different from the background. Two populations of values usually represent them: the lowest ones are interpreted as analytical noise, whereas the highest positive ones above the threshold value (TV) are assumed to express intrusive events. A Gaussian mixture model was used to decompose the peak component, i.e. to analyse the histogram plot of the peak-component frequency distribution and to choose the TV (MIXMOD Software; Biernacki et al., 2006; Fig. 4b). This model helps to disentangle two overlapping sub-distributions and to identify the upper limit of the main distribution, which may potentially be the upper limit of the analytical noise-related variation. The distribution of peaks along the sequence is evaluated by the smoothing sum of episodes with a 50 or $100 \mathrm{yr}$ moving time window. The reconstruction of flood-event frequency, from cores LL08-1 and LL08-2, results from this time-series analysis of the peak components (Fig. 5). According to the lithological classification presented Sect. 3.1, naked-eye counting of the darkbrown flood deposits has been performed three times by three different persons. The results were averaged to produce a 

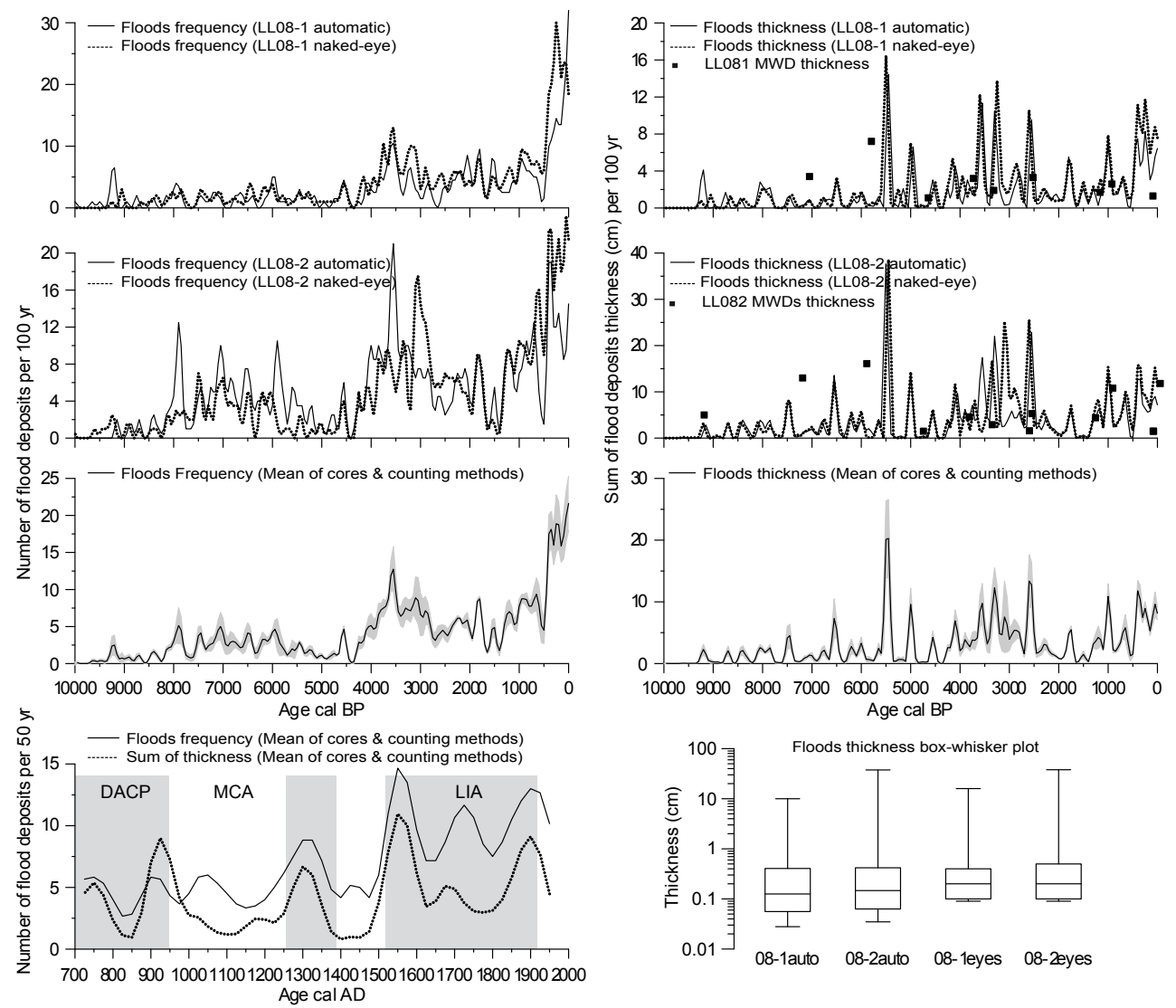

Fig. 5. Flood frequency and thickness sum per $100 \mathrm{yr}$ for both cores (LL08-1 and LL08-2) and from both naked-eye and automatic counting methods; thickness of mass-wasting deposits from both cores; average curves from the four inferred records and their descriptive statistics are presented in the bottom-left diagram and in Table 2, respectively. Main periods of flood frequency increase are underlined by gray bands. A magnified view of detailed flood frequency (events per $50 \mathrm{yr}$ ) covering the last $1300 \mathrm{yr}$ is plotted at the bottom-left of the figure. Main climatic periods are indicated: Dark Ages Colp Period (DACP), Medieval Climate Anomaly (MCA), Little Ice Age (LIA).

naked-eye counting value. Flood event frequency and the sum of thickness per $100 \mathrm{yr}$ are presented in Fig. 5 .

Results from both counting methods appear very similar if we consider the number of identified layers, the mean thicknesses or the standard deviations. The $20 \%$ supplementary flood event deposits identified in the proximal-delta core LL08-2 are well distributed along the series and does not introduce difference between both LL08-1 and LL08-2 flood frequency records. The box-plots presented in Fig. 5 illustrate the similar distribution of values from flood events quantifications (Table 2), which indicates the low amount of variability in the signals obtained from the two cores and methods. This confirms that the reconstructed flood signal depends neither on the core location in the lacustrine basin nor on the identification/counting methods used for quantifying sedimentary event deposits.

Flood frequency appears low until 4500-4000 cal BP, except for small increases at ca. 8000, 7500, 7100, 6500 and $6000 \mathrm{cal}$ BP. Then, an abrupt increase is recorded between 4000 and 2800 cal BP, followed by a slight decrease until
$1300 \mathrm{cal}$ BP (650 cal AD). A new strong increase occurs after ca. $450 \mathrm{cal} \mathrm{BP}(1500 \mathrm{cal} \mathrm{AD})$, reaching a maximum at ca. 150 cal BP (1800 cal AD). The bottom-left diagram of Fig. 5 shows the detailed reconstruction of flood frequency for the last $1300 \mathrm{yr}$, a period that includes the Dark Ages Cold Period, the Medieval Climate Anomaly and the Little Ice Age. Seven periods of elevated flood frequency are recorded around $750,900,1150,1300,1550$ and $1850 \mathrm{cal} \mathrm{AD}$. The sum of flood thickness per $100 \mathrm{yr}$ shows a similar record of flood activity except for four additional short and abrupt increases, which correspond to punctual thick flood deposits in ca. $6600,5600,5100$ and $2700 \mathrm{cal}$ BP. Mass-wasting deposits are also plotted in Fig. 5: most of the events are recorded during the last $4500 \mathrm{cal} \mathrm{BP}$, only 3 events occur earlier, around 9200, 7200 and 5900 cal BP.

\subsection{Background sedimentation changes}

Figure 6 presents geophysical and geochemical descriptors of the whole LL08-1 sequence, including density of sediments, magnetic susceptibility and the $\mathrm{Ca} / \mathrm{K}$ ratio calculated 


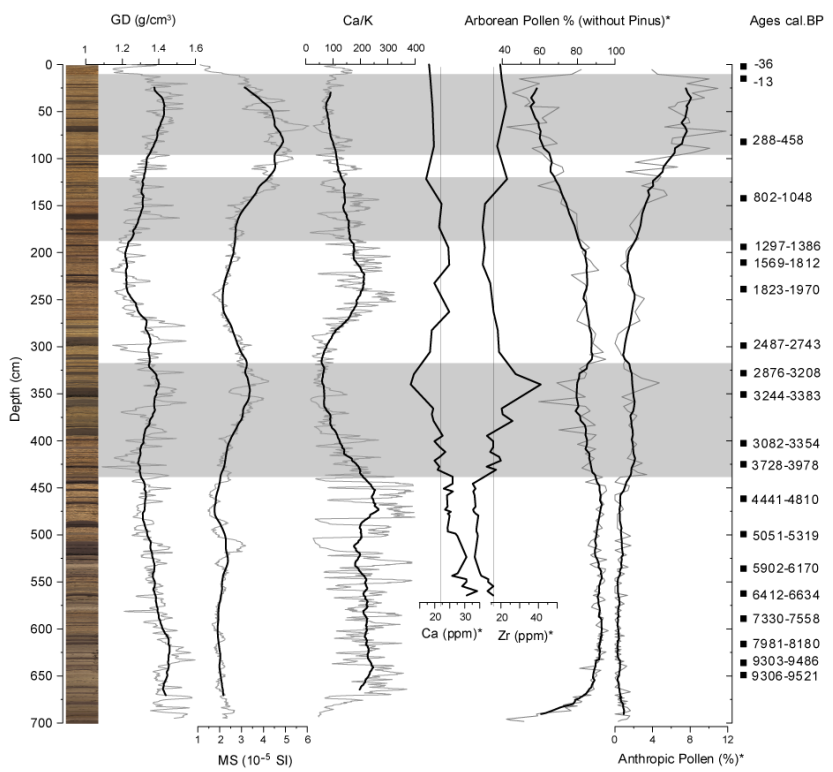

Fig. 6. Geophysical and geochemical proxies from the entire master core LL08-1, with calibrated radiocarbon ages. *Pollen analyses, $\mathrm{Zr}$ and Ca ICP-AES concentration measurements have been made on background sedimentation only. The $\mathrm{Ca} / \mathrm{K}$ ratio is calculated from $\mathrm{XRF}$ measurements from the entire master core, as well as Gamma Density (GD) and Magnetic Susceptibility (MS) data. Grey bands show the main phases of sedimentological and vegetation covers change and marked by anthropic pollen indicator increase.

from core scanning. Calcium can be considered a proxy for autochthonous sedimentation (mainly derived from authigenic precipitation in the water column), while potassium is mainly linked to clays and may be considered a proxy for allochthonous sedimentation. The low-frequency smoothing of the data highlights the main trend of the sedimentary dynamics during the last ten millennia, i.e. the change in sediment composition associated with environmental changes, excluding sedimentary events. The $\mathrm{Ca} / \mathrm{K}$ ratio that allows us to partially correct for drifts is used to track allochthonous inputs (represented by $\mathrm{K}$ ) versus mineral autochthonous precipitation $(\mathrm{Ca})$. Ca can also be detritic, as the watershed is dominated by Dolomite. Complementary calcium and zirconium elemental analyses from samples of discrete laminated facies characterise the background sedimentation.

All of these proxies show a significant change of background lacustrine sedimentation at ca. 4000. This means that, during the Bronze Age, there was an increase in GD, MS and allochthonous components $(\mathrm{K}, \mathrm{Zr})$, which indicates higher erosion in the watershed of Lake Ledro. GD, MS and $\mathrm{Ca} / \mathrm{K}$ show that this high allochthonous contribution to sedimentation continues until ca. 3000-2800 cal BP. This is also indicated by the increase in SAR (Fig. 3). Autigenic sedimentation becomes dominant between 2800 and 1200 cal BP. But around 1200-1000 cal BP (750-950 cal AD), all proxies record a new increase in detrital input into the lake (SAR,
$\mathrm{MS}, \mathrm{Zr}$ and $\mathrm{Ca} / \mathrm{K}$ proxies), and a new period of soil erosion and land cover change begins in the catchment, lasting until the 20th century. Just a short interruption is observed in the period of ca. 1200-1400 cal BP (550-750 cal AD).

\subsection{Tree cover and pollen inferred land-use dynamics}

Vegetation dynamics around the lake are documented by simplified pollen data shown in Fig. 6. Land-cover changes are in agreement and confirm the interpretation of the sedimentological analyses (Fig. 6). A first phase of landscape opening and land-use occurs between ca. 4100 and $2700 \mathrm{cal} \mathrm{BP}$, during the Bronze Age, following by lower human pressure in the watershed until ca. 2300 cal BP. Between 2300 and 1700 cal BP, during the Roman period, human impact is perceptible, but remains relatively low. Then, a new phase of decline in human activities is recorded until ca. $1200 \mathrm{cal}$ BP (750 cal AD). The third phase of forest clearing and expansion of agro-pastoralism activities around the lake corresponds to the medieval period. The human impact on land crosses a new threshold and intensifies from $1000 \mathrm{cal}$ AD (950 cal BP) until the 20th century, with only a short decrease around the 13 th century $(600 \mathrm{cal} \mathrm{BP})$.

\section{Discussion}

\subsection{Sedimentary event deposits and palaeoflood regime analysis}

Changes in the amount, frequency and intensity of precipitation have an effect on the magnitude and timing of runoff, and thereby on the flood occurrence. Hence, long-term flood records can be used as valuable proxies of Holocene climatic variability through the analysis of variations in the temporal distribution of floods (Moreno et al., 2008). In the case of Lake Ledro, the Massangla and Pur rivers are occasionally torrential tributaries draining steep slopes. Based on the grain-size pattern and the high content of soil material and vegetation debris eroded from the drainage basin, these dark-brown sedimentary events are interpreted to be flashflood events (Gilli et al., 2013) following heavy precipitation and/or snowmelt events in the Ledro area.

The sedimentation of Lake Ledro offers one of the best systems to clearly detect and quantify flood deposits: the background sedimentation is dominated by autochthonous sedimentation (carbonate and lacustrine organic matter), and the flood deposits are marked by a high content of soil organic matter and appear as dark-brown layers that can be easily differentiated from the background in digital pictures. Using a seismic survey to find the best undisturbed sequences and analysing two cores in a proximal and distal position in the lake guarantees the quality of our record, even though there could be some heterogeneity of deposits in the lacustrine basin (Schiefer et al., 2011). 
The colour data represent a more valuable proxy than geochemistry measurements, which are affected by long-term changes in the background sedimentation with the increase in terrestrial inputs since ca. 4000 cal BP (Fig. 6). Therefore, mineral elements, like $\mathrm{Si}, \mathrm{K}, \mathrm{Fe}$ and $\mathrm{Ti}$ do not really characterise all flood deposits and present a asymmetric profile within the facies; thus, they do not allow the use of them for automatic selection and counting (Fig. 2b). Finally, we observed that this is allochthonous organic matter that better discriminate flood deposits from the background and this is allochthonous organic matter that gives the dark-brown colour to the flood deposits. This explains why colour data and the red component appear as the best proxy to extract and quantified flood signal.

For the hydrologist, a flood is a river-flow height or volume that exceeds some mean or average water flow state over a period of time. In contrast, the sedimentologist considers floods to be flows of sediment that exceed some threshold value, so that they induce significant solid particle input into the lake. Because there are numerous geomorphologic characteristics and sedimentological parameters, the thickness of flood deposits cannot be directly associated with the intensity of floods (Giguet-Covex et al., 2012). However, records of flood frequency are dependent on deposit thickness as a minimum thickness that defines the detectable layers, i.e. on floods that have led to the sedimentation of a minimum of allochthonous material. The methods and techniques used in this study were selected to detect the greatest portion of flood episodes that have occurred in the Ledro Lake catchment area and to provide the most exhaustive flood frequency reconstruction possible. The results show that, except for small punctuate differences, both frequency and thickness records offer the same pattern: deposit thickness increases when frequency increases, and vice-versa (Fig. 5). Only the rarest, thickest events $(>5 \mathrm{~cm})$ seem to occur during periods of low or moderate flood frequency, such as those at ca. 6500, 5500, $5000,3500,3200,2500 \mathrm{cal} \mathrm{BP}$, which may reflect strong remobilisation and discharge of material stocked in the watershed during a low flooding or dryer period.

\subsection{Four successive periods of palaeoenvironmental changes}

Figure 6 shows that, independent of the event deposits, the background sedimentation of Lake Ledro records four main periods:

- Before 4100 cal BP, detrital flux into the lake is very low, and the vegetation around the lake is a closed forest. Pollen-inferred anthropogenic activities indicate low human impact (Joannin et al., 2013).

- After $4100 \mathrm{cal}$ BP (2150 cal BC) and until $2700 \mathrm{cal} \mathrm{BP}$ (750 cal BC), environmental dynamics are marked by an increase in detrital inputs into the lake (SAR, MS, K and $\mathrm{Zr}$ increases) and increased pollen, indicating hu- man activities. Meanwhile, the number of arboreal taxa decreases. This clearly indicates an increase in soil erosion, which fits with human forest clearing and the development of agro-pastoral activities. This is in agreement with the Bronze Age settlement found on the lake shores by an archaeological survey (Pinton and Carrara, 2007).

- The third period, from 2700 to $1200 \mathrm{cal} \mathrm{BP}(750 \mathrm{cal} \mathrm{BC}$ and $750 \mathrm{cal}$ AD), encompasses the Iron Ages and the Roman and Early Medieval periods. During these periods, human activities seem relatively limited: the forest recovers and erosion strongly diminishes. Only a small increase in anthropogenic pollen (from 2300 to $1700 \mathrm{cal}$ BP) indicates a human presence in the watershed that is most likely less marked by pastoralism than by crop cultivation, which in turn has a reduced effect on the forested area (Joannin et al., 2013). From 1700 to 1200 cal BP, the reduction of agro-pastoral activities may be associated with the massive migration period (Tinner et al., 2003; Büntgen et al., 2011).

- The last period of environmental change is from 1200 cal BP (750 cal AD) to the 19th century, i.e. the Middle and Modern Ages. A new increase in allochthonous input into the lake follows the opening of the forest and the expansion of human activities around the lake. This fourth period is abruptly and briefly interrupted around $700 \mathrm{cal}$ BP (1350 cal AD), at the time of the European Black Death and Great Famine (Büntgen et al., 2011).

The last thick flood deposit recorded in the cores is dated to $1920 \pm 20 \mathrm{AD}$. In the 20th century, the sedimentation appears strongly modified by the human control: hydropower production since $1929 \mathrm{AD}$ can modify the temperature of the water column and prevent from hyperpycnal flood occurrences and/or recent human infrastructure on river corrections in the catchment area have reduce the impact of flash-flood events on lacustrine environments; consequently, the record cannot be used for palaeoenvironmental reconstruction.

\subsection{Variability in flood frequency in the early to mid-Holocene and possible orbital control}

Over the last $10000 \mathrm{yr}$, Lake Ledro's flood record shows two distinct periods, with clustering of flood events at 8000-7000 BP and after 4500-4000 cal BP (Fig. 7). In detail, the high and low frequency variability, i.e. above the millennial trend, notes a secular variability that correlates well with the Ledro lake-level reconstruction (Magny et al., 2012). The three successive increases in flood frequency and lake level ca. 8000, 7500 , and $7000 \mathrm{cal}$ BP appear to be the most prominent events in the early to mid-Holocene at Lake Ledro. They seem synchronous with a major change in reconstructed summer temperature deviation in southwestern Europe (Fig. 7; 


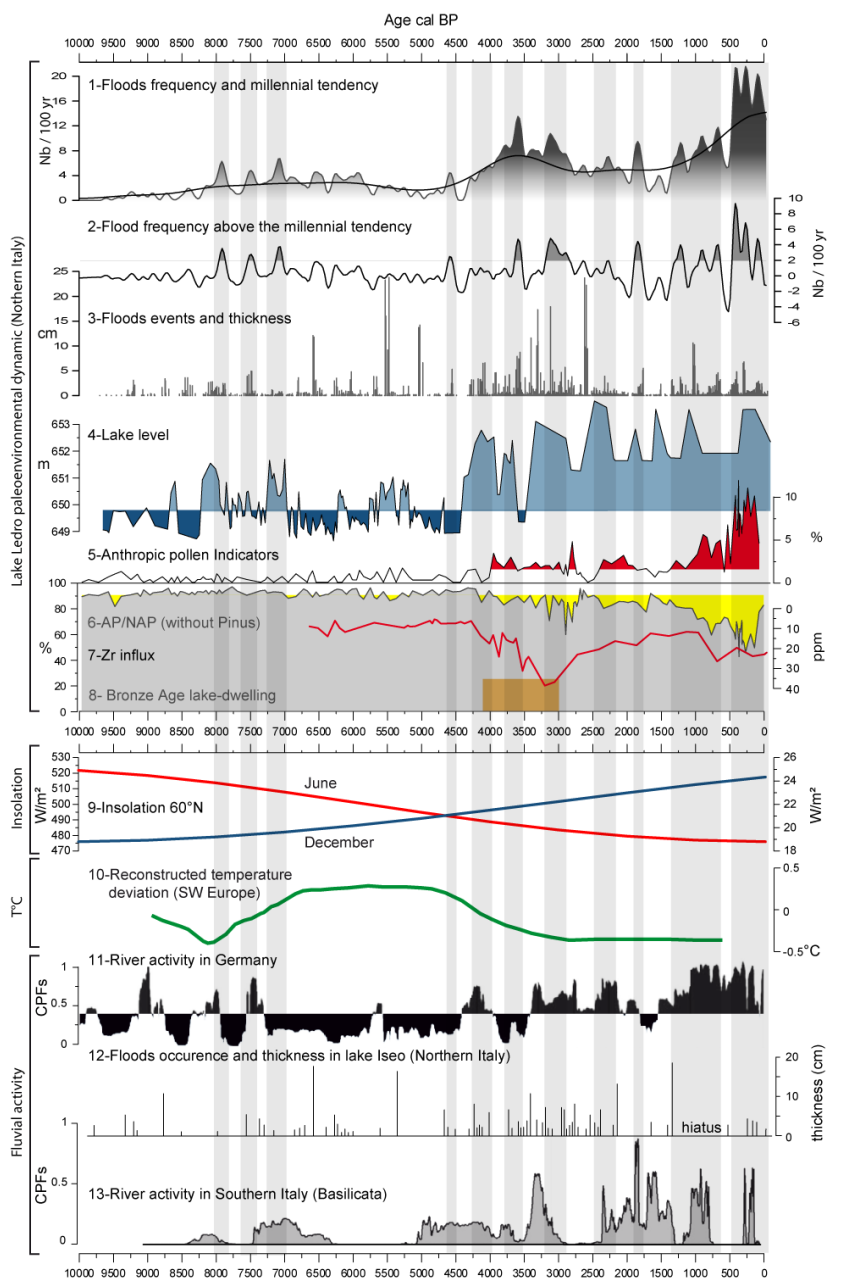

Fig. 7. Lake Ledro's results compared with other regional and continental records of climate and environmental changes. 1 - Flooddeposit frequency, with the millennial trend; 2 - Submillennial flood deposit frequency, i.e. above the millennial trend (dashed: 2 times greater); 3 - Flood events and thicknesses (1 to 3: Lake Ledro deep cores LL08-1 \& 2; this study); 4 - Lake Ledro lake levels (littoral cores; Magny et al., 2012); 5 - Anthropogenic pollen (see text for the list of taxa); 6 - Arboreal pollen (5 \& 6: Ledro deep core LL081; Joannin et al., 2013); 7 - Zr ICP-AES concentration (Ledro deep core LL08-1); 8 - Chronology of the Bronze Age lake dwellings (see location on Fig. 1a; Pinton and Carrara, 2007); 9 - June and December insolation at $60^{\circ} \mathrm{N}$ (Berger and Loutre, 1991); $10-\mathrm{Re}-$ constructed deviation of summer temperatures from pollen data for SW Europe (Renssen et al., 2009); 11 - Cumulative probability density functions of ${ }^{14} \mathrm{C}$ dates associated with major floods in Germany (Hoffmann et al., 2008); 12 - Flood events and thicknesses from Lake Iseo (50 km SW from Lake Ledro; Lauterbach et al., 2012); 13 - Cumulative probability density functions of ${ }^{14} \mathrm{C}$ dates associated with major flooding in Basilicata, southern Italy (Piccarreta et al., 2011). Grey bands underline periods of flood frequency increase at Lake Ledro.
Renssen et al., 2009). Also at this time, the Holocene SST record from marine core MD90-917 in the Adriatic Sea highlights major negative anomalies (Siani et al., 2010). This period, 8000-7000 cal BP, corresponds to the highest rate of change in annual insolation for the Holocene (Zhao et al., 2010) and a prolonged period of decrease in the residual atmospheric radiocarbon (Stuiver et al., 1998). The higher flood activity may have been driven by a combination of orbital forcing and change in solar activity. In a broad sense, these increases in flood frequency occur during periods of global cooling marked by major glacier advances in the Alps (Matthews and Dresser, 2008). Between ca. 6000 and 4500 cal BP, Ledro's flood frequency is relatively low, except for a few very thick deposits that are synchronous with a lakelevel rise around 5800-5300 cal BP. This coincides with a major worldwide cooling event (Magny et al., 2006). Figure 7 also shows similar increases in flood activity in the nearby Lake Iseo (50 km southwest of Lake Ledro; Lauterbach et al., 2012), in southern Italy (Piccarreta et al., 2011), in the Alps (Debret et al., 2010) and in Germany (Hoffmann et al., 2008). All of these authors postulate that flooding periods are climatically driven and mainly associated with colder and moister periods, at least until 4000 to $2000 \mathrm{cal}$ BP. Around $4300-4000$ cal BP, the ecosystems of the Alps and the northern Mediterranean experienced a major change (the Neoglacial; Zanchetta et al., 2012), including reduced fire activity (Vannière et al., 2011), rising lake levels (Magny et al., 2009) and glacier advances (Matthews and Dresser, 2008). Superimposed on this multicentury climate variability, the multimillennial trend of summer temperature shows a decline (Fig. 7; Renssen et al., 2009). Such a trend is in line with the precessional signal found in insolation at $60^{\circ} \mathrm{N}$ (Berger and Loutre, 1991): the decreased seasonal contrast of insolation reached its halfway point at this time. Synchronously, the period of flood frequency increase around 4500-4000 cal BP at Lake Ledro suggests a change in the long-term palaeohydrological regime, with a long-term repetition of period of high flood frequencies, which is also at the European scale (Fig. 7). This rupture may reflect a nonlinear climate response to the orbitally driven gradual decrease in summer insolation, which controls the millennial trend toward wet conditions during the late-Holocene (Mayewski et al., 2004; Zhao et al., 2010).

\subsection{Variability of flood frequency during the mid- to late-Holocene and imprint of human activities}

The millennial trend of Lake Ledro's flood frequency shows two marked steps changes in the rate of increase around 4500-4000 cal BP and $500 \mathrm{cal} \mathrm{BP,} \mathrm{coinciding} \mathrm{with} \mathrm{known}$ global climate changes. These changes in flood dynamics are also synchronous with forest openings, soil erosion and an increase in land use in the Lake Ledro watershed; the earlier one is contemporaneous with protohistoric lake-dwelling settlements (Fig. 7; Pinton and Carrara, 2007). This suggests 
that at least part of the flood activity and/or the repetition of intense events, as shown by the increase of mean thickness increase of flood deposits, is linked with human activities. At the regional scale, pollen data provide strong evidence for regional anthropogenic influence, such as forest clearings and agricultural activity (Mercuri et al., 2006; Valsecchi et al., 2006). In the western Swiss Alps, changes in Holocene vegetation are characterised by continuous landscape denudation that begins at ca. 4300 cal. yr BP, with several distinct pulses of increasing deforestation. Each pulse can be attributed to an increase in pollen-inferred human impact and corresponds to increased landslide activity in the Lake Schwarzsee catchment area, as recorded by higher sedimentary event frequencies in the sediment record (Dapples et al., 2002).

Similarly, Macklin and Lewin (2003) reconstruct the flood frequency in Britain through the Holocene. A significant increase around 4500-4000 cal BP in their data suggests that land use has increased the sensitivity of both lowland and upland British environments. They conclude that land use plays a key role in moderating or amplifying the sensitivity to climate. Hoffmann et al. (2008; Fig. 7) show from the compilation of a database of 506 fluvial ${ }^{14} \mathrm{C}$ ages from Germany that, after 4500-4000 cal BP, the increased soil erosion is at least partially due to the Bronze Age growing population and intensive agricultural activities and cannot be unequivocally attributed to climate. Across central and southern Europe, studies reveal a striking synchronism in soil impacted by land use. This suggests similar land-use practices over wide areas, marked by the fire and grazing development that characterises the Bronze Age (Rius et al., 2009; Vannière et al., 2008). During this period, around the Mediterranean basin, the fire regime switches from being predominantly climateforced to being human-driven (Vannière et al., 2008, 2011).

These observations raise the question, how were the Bronze Age populations able to transform large areas so rapidly? Although the relative contributions of climate and land use are difficult to quantify, the results obtained from Lake Ledro help to answer questions about the magnitude of ecosystem changes and about the timescales. During the period 4000-3000 yr ago, the Bronze Age population was most likely large enough to contribute to a widespread and strong increase in land erosion. The major change in the hydrological regime that traduces the Neoglacial initiation and that is recorded in particular by lake-level variability (Magny et al., 2012) at Lake Ledro, probably leads to the flooding increase. This shift in flood frequency ca. $4000 \mathrm{cal}$ BP is thus the results of both forcing factors.

\subsection{Variability in flood frequency during the last millennium and possible solar control}

To assess the main drivers of flood frequency during the last centuries and to interpret long-term changes in flood frequency, chronologies of high- and low-frequency variability were compared with independent and regional flood records

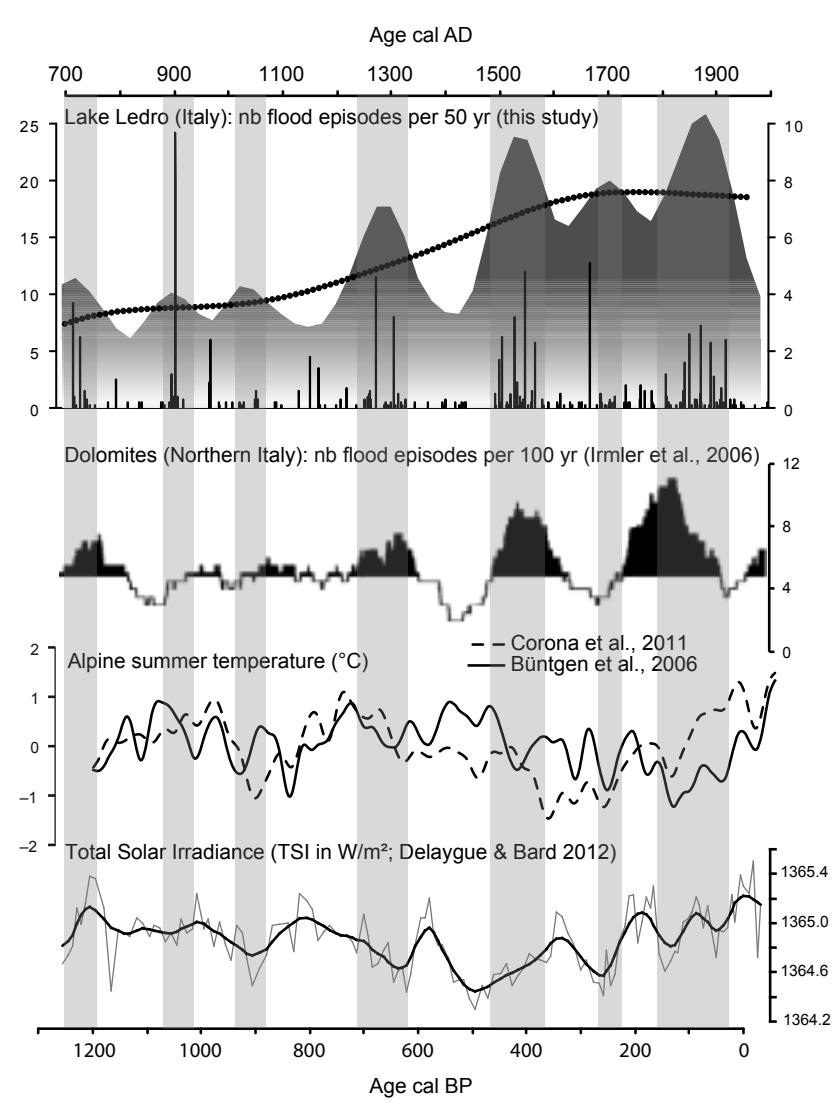

Fig. 8. Lake Ledro's flood frequency for the last $1300 \mathrm{yr}$, compared with debris flow records from Lago di Braies (Dolomite Alps, $150 \mathrm{~km}$ NE from Lake Ledro (Irmler et al., 2006), with Alpine temperatures reconstructed from tree-ring studies (Büntgen et al., 2006; Corona et al., 2011) and with total solar insolation reconstructed from ${ }^{10} \mathrm{Be}$ records (Delaygue and Bard, 2011).

and climate reconstructions (Fig. 8). The first comparison concerns the debris-flow calendar from Lago di Braies ( $150 \mathrm{~km}$ northeast of Lake Ledro; Irmler et al., 2006). Taking into account the uncertainty in the radiocarbon chronologies, both records show strong similarities in their time series. Prior to $700 \mathrm{cal} \mathrm{BP}(1250 \mathrm{cal}$ AD), flood and debrisflow frequency is relatively low, with three slight increases at ca. 1200, 1050 and 900 cal BP (750, 900 and 1150 cal $\mathrm{AD})$. A stronger increase is recorded in both records around $650 \mathrm{cal}$ BP (1300 cal AD), followed by a break of a few centuries, then followed by a major increase that reaches its first maximum at ca. $400 \mathrm{cal} \mathrm{BP}(1550 \mathrm{cal} \mathrm{AD})$ and a second maximum at ca. $100 \mathrm{cal} \mathrm{BP}(1850 \mathrm{cal} \mathrm{AD})$. These periods of maximum flood frequency since $1500 \mathrm{cal}$ AD have also been reported by Schmocker-Fackel and Naef (2010) from northern Switzerland, and they appear to be synchronous with multiple records of Spanish flood activity (Barriendo and Rodrigo, 2006; Benito et al., 2003), suggesting that these flood patterns result from large-scale climate changes at the European scale or larger. The long-term trend of increased flood 
frequency during the last millennium also contains two successive periods of low and high flood frequency, which coincide with the Medieval Warm Period (MWP) followed by the cooler Little Ice Age (LIA) from ca. 1500 to $1850 \mathrm{cal}$ $\mathrm{AD}$. This is also in agreement with the increase in flood activity during the LIA in many Mediterranean river basins (Benito et al., 2008; Moreno et al., 2008; Wilhelm et al., 2012). The comparison with Alpine summer temperature series reconstructed from tree-ring data (Büntgen et al., 2011; Corona et al., 2011) highlights a general synchronicity between summer-temperature decreases and flood-frequency increases, such that climate appears to be a significant driving factor of flood frequency variability. Finally, the comparison with the total solar irradiance record, from Beryllium-10 icecore records (Delaygue and Bard, 2011), suggests that during the last $1300 \mathrm{yr}$, flood frequency increases occurred during all minima of solar irradiance. This timing of flood frequency increases could implies that, superimposed on the local flood-producing mechanism, solar variability during the last millennium has induced a response in the hydrological regime through indirect and complex atmospheric circulation patterns (Hu et al., 2003; Mayewski et al., 2004). But this hypothesis is based on chronological correlation with important uncertainty and further studies are necessary to confirm it.

Today, the annual maximum flooding occurs during autumn from flood-producing storms due to southern air flows driven by the meridional southern circulation patterns. However, spring and summer floods occur before the extreme precipitation season due to increasing soil moisture from the late spring snow melt, whereas extreme events are more likely to occur as late as November (Parajka et al., 2010). Gaume et al. (2009) also documented a marked seasonality of flash floods and in many parts of the Alpine range, suggesting a mechanism involving extreme storms and southerly circulation patterns that cause warm and moist air to be advected from the Mediterranean Sea. All of these may explain the good correlation observed in Fig. 8 between Alpine summer temperature reconstruction and Lake Ledro's flood frequency variability. From the MWP into the LIA, the trend toward higher flood frequency could have resulted from the steepening of the meridional temperature gradient as the Alps cooled more rapidly than the Mediterranean.

\section{Conclusions}

A combination of non-destructive core-scanning techniques, detailed analysis of sediment facies and $\mathrm{AMS}{ }^{14} \mathrm{C}$ dating of terrestrial macro-remains was used to detect and characterise the Lake Ledro sediment record. Very high-resolution and continuous colour data appear to be the most relevant proxy to identify flood event deposits and to separate them from the continuous background sediments. During the early- to midHolocene, flood activity appears limited to short episodes of weak increases in flood frequency during periods of high lake levels, which indicate cooler and wetter climate conditions between 8000 and $7000 \mathrm{cal} \mathrm{BP}$. After ca. 4500-4000 cal BP, flood frequency and layer thickness strongly increase synchronously with an abrupt and long-term lake-level rise at Lake Ledro. This period of flood frequency increase corresponds to a major change in hydrological regime around Lake Ledro and is in accordance with other European records of river activity, glacier extent and other proxies of climate change under global forcing factors such as insolation. The role of climate as one of the main forcing factor in flood activity is documented, but, since the Bronze Age and later during the Middle-Ages and modern times, forest clearing and land use, as shown with pollen and archaeological data, have strongly increased soil erosion and these factors could partially explain the increases in the flood activity.

Based on these approaches and results, our data emphasise: (1) variability of flood activity during the past $10000 \mathrm{yr}$ in the catchment area of Lake Ledro has been marked by two major changes ca. 4500-4000 cal BP and 650-450 cal BP (1300-1500 cal AD); (2) coherence between Lake Ledro's flood record and a large number of flood records available from western and southern Europe, which document the influence of North-Atlantic climate variability on flood frequency at the southern edge of the Alps; (3) strong human impacts resulting in an increase in allochthonous inputs into the lake since the Bronze Age, which is also most likely a general phenomenon in Europe during this period of cultural change and demographic increase. Independently of the forcing factors that cause this major shift in sedimentary flux, the period ca. 4500-4000 cal BP appears to have been crucial in determining the trajectory of western European ecosystems. Disentangling human and climate impacts on ecosystems dynamics is quite difficult because the influence of climate on societal development is not well understood, and past societal impacts on palaeoclimate change are most likely underestimated.

Acknowledgements. Financial support for this study was provided by the French ANR "LAMA" project (directed by M. Magny and N. Combourieu-Nebout, MSHE N. Ledoux, Besançon, France), and the Swiss National Science Foundation project "FloodAlp" (Project No. 200021-121909). Many thanks go to A. Stock and J. Didier for their help in conducting fieldwork and laboratory analyses.

Edited by: N. Combourieu Nebout

\section{References}

Appleby, P.: Chronostratigraphic techniques in recents sediments, in: Tracking Environmental Change Using Lake Sediments, edited by: Last, W. and Smol, J., Basin Analysis, Corin, and Chronological Techniques, Kluwer Academic Publishers, 200 pp., 2001. 
Barriendos, M. and Rodrigo, F. S.: Study of historical flood events on Spanish rivers using documentary data, Hydrol. Sci. J., 51, 765-783, 2006.

Battarbee, R. W. and Bennion, H.: Palaeolimnology and its developing role in assessing the history and extent of human impact on lake ecosystems, J. Paleolimnol., 45, 399-404, 2011.

Benito, G., Díez-Herrero, A., and de Villalta, M. F.: Magnitude and frequency of flooding in the Tagus basin (Central Spain) over the last millennium, Clim. Change, 58, 171-192, 2003.

Benito, G., Thorndycraft, V. R., Rico, M., Sánchez-Moya, Y., and Sopeña, A.: Palaeoflood and floodplain records from Spain: Evidence for long-term climate variability and environmental changes, Geomorphology, 101, 68-77, 2008.

Berger, A. and Loutre, M. F.: Insolation values for the climate of the last 10 million years, Quaternary Sci. Rev., 10, 297-317, 1991.

Beug, H. J.: Untersuchungen zur spätglazialen Vegetationsgeschichte im Gardaseegebiet unter besonderer Berücksichtigung der mediterranen Arten, Flora, 154, 401444, 1964

Beug, H. J.: Leitfaden der Pollenbestimmung für Mitteleuropa und angrenzende Gebeite, Pfeil, München, 542 pp., 2004.

Biernacki, C., Celeux, A., Govaert, G., and Langrognet, F.: ModelBased Cluster and Discriminant Analysis with the MIXMOD Software, Comput. Stat. Data An., 51/52, 587-600, 2006.

Blaauw, M.: Methods and code for "classical" age-modelling of radiocarbon sequences, Quaternary Geochronol., 5, 512-518, 2010.

Büntgen, U., Frank, D. C., Nievergelt, D., and Esper, J.: Summer temperature variations in the European Alps, AD 755-2004, J. Climate, 19, 5606-5623, 2006.

Büntgen, U., Tegel, W., Nicolussi, K., McCormick, M., Frank, D., Trouet, V., Kaplan, J. O., Herzig, F., Heussner, K. U., Wanner, H., Luterbacher, J., and Esper J.: 2500 years of European climate variability and human susceptibility, Science, 331, 578582, doi:10.1126/science.1197175, 2011.

Chapron, E., Arnaud, F., Noël, H., Revel, M., Desmet, M., and Perdereau, L.: Rhone River flood deposits in Lake Le Bourget: a proxy for Holocene environmental changes in the NW Alps, France, Boreas, 34, 404-416, 2005.

Corona, C., Edouard, J.-L., Guibal, F., Guiot, J., Bernard, S., Thomas, A., and Denelle, N.: Long-term summer (AD751-2008) temperature fluctuation in the French Alps based on tree-ring data, Boreas, 40, 351-366, 2011.

Coulthard, J. C. and Macklin, M. G.: How sensitive are river systems to climate and land-use changes? A model based evaluation, J. Quaternary Sci., 16, 347-351, 2001.

Dapples, F., van Leeuwen, A. F., van der Knaap, J. F. N., Dimitriadis, S., and Oswald, D.: Paleolimnological evidence for increased landslide activity due to forest clearing and land-use since 3600 cal BP in the western Swiss Alps, J. Paleolimnol., 27, 239-248, 2002.

Dearing, J. A. and Jones, R. T.: Coupling temporal and spatial dimensions of global sediment flux through lake and marine sediment records, Global Planet. Change, 39, 147-168, 2003.

Dearing, J. A., Battarbee, R. W., Dikau, R., Larocque, I., and Oldfield, F.: Human-environment interactions: learning from the past, Reg. Environ. Change, 6, 1-16, 2006.

Debret, M., Chapron, E., Desmet, M., Rolland-Revel, M., Magand, O., Trentesaux, A., Bout-Roumazeille, V., Nomade, J., and Ar- naud, F.: North western Alps Holocene paleohydrology recorded by flooding activity in Lake Le Bourget, France, Quaternary Sci. Rev., 29, 2185-2200, 2010.

Delaygue, G. and Bard, E.: An Antarctic view of Beryllium-10 and solar activity for the past millennium, Clim. Dynam., 36, 22012218, 2011.

Gaume, E., Bain, V., Bernardara, P., Newinger, O., Barbuc, M., Bateman, A., Blaškovicová, L., Blöschl, G., Borga, M., Dumitrescu, A., Daliakopoulos, I., Garcia, J., Irimescu, A., Kohnova, S., Koutroulis, A., Marchi, L., Matreata, S., Medina, V., Preciso, E., Sempere-Torres, D., Stancalie, G., Szolgay, J., Tsanis, I., Velasco, D., and Viglione, A.: A compilation of data on European flash floods, J. Hydrol., 367, 70-78, 2009.

Giguet-Covex, C., Arnaud, F., Poulenard, J., Disnar, J. R., Delhon, C., Francus, P., David, F., Enters, D., Rey, P. J., and Delannoy, J. J.: Changes in erosion patterns during the Holocene in a currently treeless subalpine catchment inferred from lake sediment geochemistry (Lake Anterne, $2063 \mathrm{~m}$ asl, NW French Alps): the role of climate and human activities, Holocene, 21, 651-665, 2011.

Gilli, A., Anselmetti, F. S., Glur, L., and Wirth, S. B.: Lake sediments as archives of reccurrence rates and intensities of past flood events, in: Dating torrential processes on fans and cones - methods and their application for hazard and risk assessment, edited by: Michelle Schneuwly-Bollschweiler, M. S., Stoffel, M., and Rudolf-Miklau, F., Advances in Global Change Research, 47, Springer, 2013.

Gunn, D. E. and Best, A. I.: A new automated non-destructive system for high resolution multi-sensor core logging of open sediment cores, Geo-Mar. Lett., 18, 70-77, 1998.

Hoffmann, T., Lang, A., and Dikau, R.: Holocene river activity: analysing 14C-dated fluvial and colluvial sediments from Germany, Quaternary Sci. Rev., 27, 2031-2040, 2008.

Hoffmann, T., Erkens, G., Gerlach, R., Klostermann, J., and Lang, A.: Trends of controls of Holocene floodplain sedimentation in the Rhine catchment, Catena, 77, 96-106, 2010.

Hu, F. S., Kaufman, D., Yoneji, S., Nelson, D., Shemesh, A., Huang, Y., Tian, J., Bond, G., Clegg, B., and Brown, T.: Cyclic Variation and Solar Forcing of Holocene Climate in the Alaskan Subarctic, Science, 301, 1890-1893, 2003.

Fanetti, D., Anselmetti, F. S., Chapron, E., Sturm, M., and Vezzoli, L.: Megaturbidite deposits in the Holocene basin fill of Lake Como (Southern Alps, Italy), Palaeogeogr. Palaeocl., 259, 323340, 2008.

Irmler, R., Daut, G., and Mäusbacher, R.: A debris flow calendar derived from sediments of lake Lago di Braies (N. Italy), Geomorphology, 77, 69-78, 2006.

Joannin, S., Vannière, B., Galop, D., Peyron, O., Haas, J. N., Gilli, A., Chapron, E., Wirth, S. B., Anselmetti, F., Desmet, M., and Magny, M.: Climate and vegetation changes during the Lateglacial and early-middle Holocene at Lake Ledro (southern Alps, Italy), Clim. Past, 9, 913-933, doi:10.5194/cp-9-913-2013, 2013.

Knox, J. C.: Sensitivity of modern and Holocene floods to climate change, Quaternary Sci. Rev., 19, 439-457, 2000.

Lauterbach, S., Chapron, E., Brauer, A., Hüls, M., Gilli, A., Arnaud, F., Piccin, A., Nomade, J., Desmet, M., and von Grafenstein, U.: A sedimentary record of Holocene surface runoff events and earthquake activity from Lake Iseo (Southern Alps, Italy), The Holocene, 22, 749-760, 2012. 
Lenton, T. M., Held, H., Kriegler, E., Hall, J. W., Lucht, W., Rahmstorf, S., and Schellnhuber, H. J.: Tipping Elements in the Earth's Climate System, Proc. Natl. Acad. Sci., 105, 1786-1793, 2008.

Long, C. J., Whitlock, C., Bartlein, P. J., and Millspaugh, S. H.: A 9000-year fire history from the Oregon Coast Range, based on a high-resolution charcoal study, Can. J. Forest Res., 28, 774-787, 1998.

Lotter, A. F., Sturm, M., Teranes, J. L., and Wehrli, B.: Varve formation since 1885 and high-resolution varve analyses in hypertrophic Baldeggersee (Switzerland), Aquat. Sci., 59, 304-325, 1997.

Macklin, M. G. and Lewin, J.: River sediments, great floods and centennial-scale Holocene climate change, J. Quaternary Sci., 18, 101-105, 2003.

Macklin, M. G., Benito, G., Gregory, K. J., Johnstone, E., Lewin, J., Michczynska, D. J., Soja, R., Starkel, L., and Thorndycraft, V. R.: Past hydrological events reflected in the Holocene fluvial record of Europe, Catena, 66, 145-154, 2006.

Magny, M., Leuzinger, U., Bortenschlager, S., and Haas, J. N.: Tripartite climate reversal in Central Europe 5600-5300 years ago, Quaternary Res., 65, 3-19, 2006.

Magny, M., Vannière, B., Zanchetta, G., Fouache, E., Touchais, G., Petrika, L., Coussot, C., Walter-Simonnet, A. V., and Arnaud, F.: Possible complexity of the climatic event around 4300-3800 cal. BP in the central and western Mediterranean, The Holocene, 19, 1-11, 2009.

Magny, M., Vannière, B., Calo, C., Millet, L., Leroux, A., Peyron, O., Zanchetta, G., La Mantia, T., and Tinner, W.: Holocene hydrological changes in south-western Mediterranean as recorded by lake-level fluctuations at Lago Preola, a coastal lake in southern Sicily, Italy, Quaternary Sci. Rev., 30, 2459-2475, 2011.

Magny, M., Joannin, S., Galop, D., Vannière, B., Haas, J. N., Basseti, M., Bellintani, P., Scandolari, R., and Desmet, M.: Holocene paleohydrological changes in the northern Mediterranean borderlands as reflected by the lake-level record of Lake Ledro, northeastern Italy, Quaternary Res., 77, 382-396., 2012.

Mangili, C., Brauer, A., Moscariello, A., and Naumann, R.: Microfacies of detrital event layers deposited in Quaternary varved lake sediments of the Piànico-Sèllere Basin (northern Italy), Sedimentology, 52, 927-943, 2005.

Matthews, J. A. and Dresser, P. Q.: Holocene glavcier varaition chronology of the Smørstabbtindan massif, Jotunheimen, southern Norway, and the recognition of Century- to millenial-scale European Neoglacial Events, The Holocene, 18, 181-201, 2008.

Mayewski, P. A., Rohling, E., Stager, C., Karlén, W., Maasch, K. A., Meeker, L. D., Meyerson, E., Gasse, F., van Kreveld, S., Holmgren, K., Lee-Thorp, J., Rosqvist, G., Rack, F., Staubwasser, M., and Schneider, R.: Holocene climate variability, Quaternary Res., 62, 243-255, 2004.

Mercuri, A. M., Accorsi, C. A., Mazzanti, M. B., Bosi, G., Cardarelli, A., Labate, D., Marchesini, M., and Grandi, G. T.: Economy and environment of Bronze Age settlements - Terramaras on the Po Plain (Northern Italy): first results from the archaeobotanical research at the Terramara di Montale, Veg. Hist. Archaeobot., 16, 43-60, 2006.

Meyers, P. and Lallier-Vergès, E.: Lacustrine sedimentary organic matter records of Late Quaternary paleoclimates, J. Paleolimnol., 21, 345-372, 1999.
Millet, L., Vannière, B., Verneaux, V., Mangy, M., Disnar, J. R., Laggoun-Défarge, F., Walter-Simonnet, A. V., Bossuet, G., Ortu, E., and de Beaulieu, J. L.: Response of littoral chironomid communities and organic matter to late glacial lake-level, vegetation and climate changes at Lago dell'Accesa (Tuscany, Italy), J. Paleolimnol., 38, 525-539, 2007.

Moore, P. D., Webb, J. A., and Collinson, M. E.: Pollen Analysis, Blackwell Scientific Publications, London, 1991.

Moreno, A., Valero-Garcés, B. L., Gonzales-Sampériz, P., and Rico, M.: Flood response to rainfall variability during the last 2000 years inferred from the Taravilla Lake record (Central Iberian Range, Spain), J. Paleolimnol, 40, 943-961, 2008.

Mulder, T. and Alexander, J. The physical character of subaqueous sedimentary density flows and their deposits, Sedimentology, 48, 269-299, 2001.

Mulder, T. and Chapron, E.: Flood deposits in continental and marine environments: character and significance, in: Sediment transfer from shelf to deep water - Revisiting the delivery system, edited by: Slatt, R. M. and Zavala, C., AAPG Studies in Geology, 61, 1-30, 2011.

Mulder, T., Syvitski, J. P. M., Migeon, S., Faugères, J. C., and Savoye, B.: Marine hyperpycnal flows: initiation, behavior and related deposits, A review, Mari. Petrol. Geol., 20, 861-882, 2003.

Parajka, J., Kohnova, S., Balint, G., Barbuc, M., Borga, M., Claps, P., Cheval, S., Gaume, E., Hlavcova, K., Merz, R., Pfaundler, M., Stancalie, G., Szolgay, J., and Bloschl, G.: Seasonal characteristics of flood regimes across the Alpine-Carpathian range, J. Hydrol., 394, 78-89, 2010.

Piccarreta, M., Caldara, M., Capolongo, D., and Boenzi, F.: Holocene geomorphic activity related to climatic change and human impact in Basilicata, Southern Italy, Geomorphology, 128, 137-147, 2011.

Pinton, V. and Carrara, N.: La collezione della palafitta di Ledro del Museo di Antropologia dell'Università di Padova: ricostruzione del paleoambiente. Annali dell'Università degli Studi di Ferrara - Museologia Scientifica e Naturalistica, Special Volume, 11-14, 2007.

Reille, M.: Pollen et spores d'Europe et d'Afrique du nord. Laboratoire de Botanique Historique et Palynologie, Université d'AixMarseille, France, 1992-1998.

Reimer, P. J., Baillie, M. G. L., Bard, E., Bayliss, A., Beck, J. W., Blackwell, P. G., Bronk Ramsey, C., Buck, C. E., Burr, G. S., Edwards, R. L., Friedrich, M., Grootes, P. M., Guilderson, T. P., Hajdas, I., Heaton, T. J., Hogg, A. G., Hughen, K. A., Kaiser, K. F., Kromer, B., McCormac, F. G., Manning, S. W., Reimer, R. W., Richards, D. A., Southon, J. R., Talamo, S., Turney, C. S. M., van der Plicht, J., and Weyhenmeyer, C. E.: IntCal09 and Marine09 radiocarbon age calibration curves, $0-50,000$ years cal BP, Radiocarbon, 51, 1111-1150, 2009.

Renssen, H., Seppä, H., Heiri, O., Roche, D. M., Goosse, H., and Fichefet, T.: The spatial and temporal complexity of the Holocene thermal maximum, Nat. Geosci., 2, 411-414, 2009.

Rius, D., Vannière, B., and Galop, D.: Fire frequency and landscape management in the northwestern Pyrenean piedmont, France, since the early Neolithic ( 8000 cal. BP), The Holocene, 19, 847859, 2009.

Ruddiman, W. F.: The anthropogenic greenhouse era began thousands of years ago, Clim. Change, 61, 261-293, 2003. 
Ruddiman, W. F.: The early anthropogenic hypothesis: challenges and responses, Rev. Geophys., 45, RG4001, doi:10.1029/2006RG000207, 2007.

Schiefer, E., Gilbert, R., and Hassan, M.: A lake sediment-based proxy of floods in the Rocky Mountain Front Ranges, Canada, J. Paleolimnol., 45, 137-149, 2011.

Schmocker-Fackel, P. and Naef, F.: Changes in flood frequencies in Switzerland since 1500, Hydrol. Earth Syst. Sci., 14, 1581-1594, doi:10.5194/hess-14-1581-2010, 2010.

Schneider, R. R., Price, B., Müller, P. J., Kroon, D., and Alexander, I.: Monsoon related variations in Zaire (Congo) sediment load and influence of fluvial silicate supply on marine productivity in the east equatorial Atlantic during the last 200,000 years, Paleoceanography, 12, 463-481, 1997.

Siani, G., Paterne, M., and Colin, C.: Late Glacial to Holocene planktic foraminifera bioevents and climatic record in the South Adriatic Sea, J. Quaternary Sci., 25, 808-821, doi:10.1002/jqs.1360, 2010.

Simonneau, A., Chapron, E., Vannière, B., Wirth, S. B., Gilli, A., Di Giovanni, C., Anselmetti, F. S., Desmet, M., and Magny, M.: Mass-movement and flood-induced deposits in Lake Ledro, southern Alps, Italy: implications for Holocene palaeohydrology and natural hazards, Clim. Past, 9, 825-840, doi:10.5194/cp-9825-2013, 2013.

Stockmarr, J.: Tablets with spores used in absolute pollen analysis, Pollen et Spores, 13, 615-621, 1971.

Støren, E. N., Dahl, S. O., Nesje, A., and Paasche, Ø.: Identifying the sedimentary imprint of high-frequency Holocene river floods in lake sediments: Development and application of a new method, Quaternary Sci. Rev., 29, 3021-3033, 2010.

Stuiver, M., Reimer, P. J., Bard, E., Beck, J. W., Burr, G. S., Hughen, K. A., Kromer, B., McCormac, G., van der Plicht, J., and Spurk, M.: Intcal98 radiocarbon age calibration, 24 000-0 cal BP, Radiocarbon, 40, 1041-1083, 1998.

Tinner, W., Lotter, A. F., Ammann, B., Conedera, M., Hubschmid, P., van Leeuwen, J. F. N., and Wehrli, M.: Climatic change and contemporaneous land-use phases north and south of the Alps 2300 BC to 800 AD, Quaternary Sci. Rev., 22, 1447-1460, 2003.

Valsecchi, V., Tinner, W., Finsinger, W., and Ammann, B.: Human impact during the Bronze Age on the vegetation at Lago Lucone (northern Italy), Veg. Hist. Archaeobot., 15, 99-113, 2006.
Vannière, B., Bossuet, G., Walter-Simonnet, A.-V., Ruffaldi, P., Adatte, T., Rossy, M., and Magny, M.: High resolution record of environnemental changes and tephrochronological markers of the Last Glacial-Holocene Transition at Lake Lautrey (Jura, France), J. Quaternary Sci., 18, 797-808, 2004.

Vannière, B., Colombaroli, D., Chapron, E., Leroux, A., Tinner, W., and Magny, M.: Climate versus human-driven fire regimes in Mediterranean landscapes: the Holocene record of Lago dell'Accesa (Tuscany, Italy), Quaternary Sci. Rev., 27, 11811196, 2008.

Vannière, B., Power, M. J., Roberts, N., Tinner, W., Carrión, J., Magny, M., Bartlein, P., Colombaroli, D., Daniau, A. L., Finsinger, W., Gil-Romera, G., Kaltenrieder, P., Pini, R., Sadori, L., Turner, R., Valsecchi, V., and Vescovi, E.: CircumMediterranean fire activity and climate changes during the mid Holocene environmental transition (8500-2500 cal yr BP), The Holocene, 21, 53-73, 2011.

Vasskog, K., Nesje, A., Støren, E. N., Waldmann, N., Chapron, E., and Ariztegui, D.: A Holocene record of snow-avalanche and flood activity reconstructed from a lacustrine sedimentary sequence in Oldevatnet, western Norway, The Holocene, 21, 597614, 2011.

Wilhelm, B., Arnaud, F., Sabatier, P., Crouzet, C., Brisset, E., Chaumillon, E., Disnar, J.-R., Guiter, F., Malet, E., Reyss, J.-L., Tachikawa, K., Bard, E., and Delannoy, J.-J.: 1400 years of extreme precipitation patterns over the Mediterranean French Alps and possible forcing mechanisms, Quaternary Res., 78, 1-12, doi:10.1016/j.yqres.2012.03.003, 2012.

Zanchetta, G., Giraudi, C., Sulpizio, R., Magny, M., Drysdale R. N., and Sadori, L.: Constraining the onset of the Holocene "Neoglacial" over the central Italy using tephra layers, Quaternary Res., 78, 236-247, doi:10.1016/j.yqres.2012.05.010, 2012.

Zhao, C., Yu, Z., and Zhao, Y.: Holocene climate trend, variability, and shift documented by lacustrine stable-isotope record in the northeastern United States, Quaternary Sci. Rev., 29, 1831-1843, 2010.

Zolitschka, B., Behre, K.-E., and Schneider, J.: Human and climatic impact on the environment as derived from colluvial, fluvial and lacustrine archives - examples from the Bronze Age to the Migration period, Germany, Quaternary Sci. Rev., 22, 81100, 2003. 